\title{
Genocidio cultural: diálogos teóricos, históricos y culturales sobre la represión de $1932^{\prime}$
}

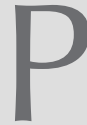

or primera vez desde los acontecimientos de 1932, los pueblos originarios de El Salvador se congregaron el pasado ocho de agosto de 2012, en el contexto del día Mundial de los Pueblos Indígenas, en el centro ceremonial El Llanito, en el Municipio de Izalco, Sonsonate, para definir un plan de lucha de unidad nacional por la reivindicación de su cultura, la búsqueda del reconocimiento estatal como sujetos de derechos y por el esclarecimiento del genocidio cultural.

Se trató de un encuentro-reconocimiento histórico entre náhuatl pipiles, lencas y cacaoperas, inédito por su forma y contenido. Para los participantes, herederos de la cultura originaria, fue un salto de calidad en su organización después de décadas de aislamiento, silencios y resistencia. Una semana después, el 15 de agosto, el relator especial de las Nacional Unidas para los Pueblos Indígenas, James Anaya, visitó a las poblaciones para recabar testimonios y demandas históricas y así recomendar al Estado salvadoreño la ratificación del Convenio 169 de la Organización Internacional del Trabajo (OIT) en materia de derechos y cultura indígena.

Estos hechos cobran relevancia sobre todo porque dejan de manifiesto la existencia colectiva de los pueblos que en 1932 fueron agredidos por el Estado a través de una feroz dictadura cívico militar, y hace patente la reivindicación de los primeros moradores de estas tierras a su existir con sus particulares formas propias de vida colectiva, así como su incansable voz de exigencia de justicia sobre aquellos sucesos trágicos del siglo xx. 
Estos mismos pueblos son fuentes primarias consultadas para la realización de la tesis de Maestría en Filosofía Iberoamericana titulada El Genocidio Cultural de 1932, Narrativas y Memorias de la Represión y que trata de un análisis en torno a las ideas y sus correlatos históricos para dar contenido al concepto de genocidio cultural como guía metodológica para nuevas investigaciones, y que para este número de Realidad presentamos un resumen, en forma de artículo, del primer ca- pítulo de la tesis titulado Genocidio Cultural, diálogos teóricos, históricos y culturales sobre la represión de 1932.

A la Alcaldía del Común de Izalco y los pueblos que la integran debo la orientación, confianza y hermandad para conocer de viva voz la palabra de los sobrevivientes de aquellos momentos y entender parte de lo que sucedió en aquella hora trágica de la historia salvadoreña.

\section{Introducción}

En la historia de las ideas sobre los acontecimientos de la rebelión y la respuesta estatal de 1932 en El Salvador se debaten concepciones sobre cómo nombrar y dar explicación a aquellos sucesos, esto la luz de nuevas evidencias primarias oficiales, testimonios recabados recientemente y diversos enfoques analíticos e interpretativos.

Este artículo se integra de 4 apartados que buscan hilar ideas, tesis y planteamientos sobre las perspectivas de estudio en la descripción, primero, de las causas tanto de la rebelión como de la respuesta represiva del gobierno militar liderado por el General Maximiliano Hernández Martínez; segundo, los conceptos y términos empleados en los diversos enfoques estudiados para describir la eliminación de amplios contingentes humanos en los sucesos de enero de 1932; tercero, la propuesta teórico metodológica del uso del término "genocidio cultural" como

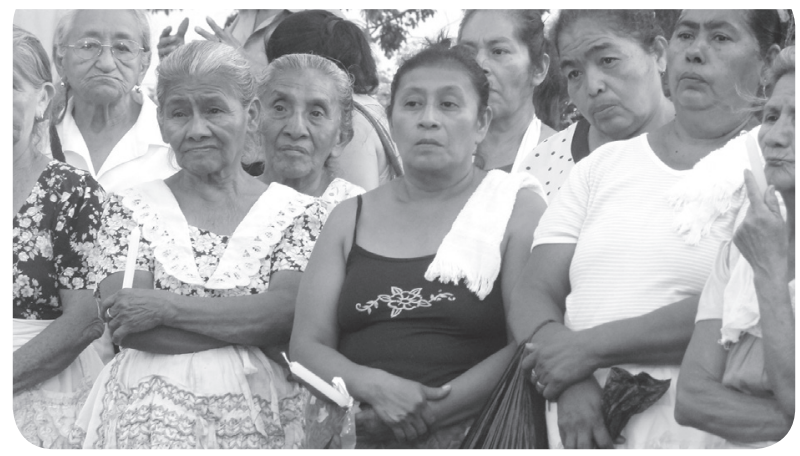


el concepto que describe, desde mi punto de vista, con mayor precisión la respuesta violenta de los órganos del Estado salvadoreño dirigido por una dictadura cívico militar. Y aquí entendemos por este término, con base en la idea plasmada en la Convención sobre Genocidio ${ }^{2}$, como: todo acto premeditado o todo acto consumado de destrucción o exterminio de un colectivo humano, en función de su origen cultural étnico, mientras cumpla todos o alguno de los siguientes considerandos: matanza de miembros del grupo; lesión grave a la integridad física y mental de los miembros del grupo; sometimiento intencional del grupo a condiciones de existencia que hayan de acarrear su destrucción físi$\mathrm{ca}$, total o parcial; medidas destinas a impedir nacimientos en el seno del grupo y traslado por fuerza de niños del grupo a otro grupo. Y el cuarto y último apartado se refiere las discusiones sobre el origen de este concepto, el genocidio cultural, desde un análisis filosófico y de la historia de las ideas que le dieron cause a partir del periodo conocido como la modernidad.

\section{Enfoques causales de la rebelión y de la respuesta estatal}

Después de los acontecimientos de 1932, historiadores salvadoreños y extranjeros, políticos de diferente signo, así como actores sociales diversos, han analizado las causas y consecuencias de la decisión que tomó el régimen liderado por el General Maximiliano Hernández Martínez de ordenar el fusilamiento en masa de miles de personas, sobre todo de aquellas de origen indígena asentadas en la zona occidental de El Salvador.

Por un lado, algunos investigadores de las ciencias sociales y políticos hablan de la "causalidad comunista" como la fuente de la rebelión y la razón por la cual el Estado respondió con el uso de la fuerza de las armas.

Las condiciones políticas internas en El Salvador alentaron a la siguiente generación de estudiosos a reconfirmar la inspiración comunista de la rebelión de 1932... Esta creencia que denominamos la explicación de la causalidad comunista, se convirtió en un referente ideológico para tanto la derecha como la izquierda de El Salvador. ${ }^{3}$

El reconocido escritor Roque Dalton en sus obras sobre El Salvador: Monografía ; y Miguel Mármol,
Los sucesos de 1932 en El Salva$d o r^{5}$, llega a la conclusión de que el Partido Comunista Salvadoreño 
(PCS) con apenas un poco más de año de vida, se puso a la altura de las circunstancias históricas para participar en el levantamiento campesino. Y coincide en sus dos escritos fundamentales sobre esta etapa histórica en que la respuesta represiva de los militares, quienes llegaron al poder mediante un golpe de Estado para imponer una dictadura cívico militar, fue con el fin de sofocar a toda costa la agitación comunista.

De tal manera que entre la espada y la pared, los comunistas escogieron el camino de morir junto a su pueblo, a la cabeza de su pueblo. ${ }^{6}$

A estas mismas conclusiones llegó también el historiador Thomas Anderson, quien en un minucioso trabajo de investigación sobre los sucesos, con extensas fuentes escritas y testimoniales, identifica a la rebelión como el resultado de la acción política comunista.

Este estudio nació de un vivo interés por la rebelión comunista de 1932 en El Salvador, acontecimiento que con frecuencia se menciona en trabajos acerca del comunismo en América Latina, pero que nunca ha sido explicado en detalle. ${ }^{7}$

Después de hacer un recorrido pormenorizado sobre el desarrollo político de la izquierda salvadoreña y su contexto nacional como internacional, Anderson va consolidando sus hipótesis de investigación en el sentido de que la formación de cuadros políticos con ideología comunista fueron a su juicio deter- minantes para la revuelta en varias localidad del occidente del país, pero que correspondía a un contexto global de dos proyecto históricos enfrentados, a saber, el capitalismo, representado por la dictadura de Martínez, y el comunismo, representado por los "comunistas" alzados.

La rebelión no fue una mera jacquerine, no fue el producto de un repentino impulso de los campesinos indigenas. Por el contrario fue el resultado de una larga cadena de sucesos, acaecidos dentro del país como fuera de él. Además se distingue por ser el primer movimiento revolucionario latinoamericano en el cual desempeñaron el papel más importante hombres considerados como comunistas internacionales. ${ }^{8}$ 
Desde otra perspectiva, pero en la misma línea de categorizar los acontecimientos del 32 como una conspiración roja, la versión oficial se centró en acusar a los comunistas de estar detrás de la insurrección, planificar y organizar la rebelión. El General Maximiliano Hernández
Martínez dio a conocer en un pronunciamiento oficial fechado el 23 de enero de 1932 que el ejército y los órganos de seguridad ejecutaron acciones contra la población insurrecta con el fin de evitar el accionar de los comunistas en la zona occidental del país.

En los últimos días, el gobierno se ha visto frente a graves acontecimientos de origen comunista $y$, con fundamento a las leyes patrias, ha tenido la imprescindible necesidad de sofocarlos con mano fuerte. ${ }^{9}$

El mismo gobierno cívico militar expuso que la respuesta efectiva y total de las fuerzas armadas fue con el fin de evitar la conspiración comunista, que buscaba desestabi- lizar el orden público y hundir al país en un crisis sin precedentes por lo que ameritaba, según su concepción, usar toda la fuerza del Estado.

Por eso lamenta el Gobierno el derramamiento de sangre y las restricciones a las libertades, que se vio obligado a decretar para reprimir las vandálicas actividades comunistas, pero tiene la confianza en que una vez el pueblo salvadoreño forme con el gobierno un solo bloc de defensa, la paz, el orden constitucional y el régimen de libertad volverán a restaurarse, garantizados por la ideología política emancipadora que forma a los hombres del actual gobierno. ${ }^{10}$

Estos enfoque tanto oficiales como interpretativos contrastan con algunas fuentes primarias del movimiento comunista internacional que evaluaron la limitada participación del PCS o de grupos con la misma línea política. El Comité de Investigación del Buró del Caribe, con sede en Nueva York y perteneciente a la Tercera Internacional Comintern, hizo una evaluación hacia finales de 1932 sobre los sucesos de enero tras recibir testimonios de dirigentes comunistas salvadoreños. En un extenso texto accesible hoy en el Centro Ruso para la Conservación y el Estudio de Documentos de la Historia más Reciente, concluye:

La otra lección de los eventos es muy grave y peligrosa que queda al descubierto por los acontecimientos que han surgido en El Salvador, esto es que no existe un gran partido 
comunista de masas para orientar a este gran movimiento, organizar a las masas y dirigirlas por el camino que resulta en la tensión de la lucha de clases, en la tensión de la dirección de clase, en la tensión de las organizaciones revolucionarias de las masas. En El Salvador, más que en cualquier otro lugar, hemos visto en la práctica esos grandes daños que emergen en el movimiento revolucionario de masas, cuando no se encuentra un fuerte partido comunista de masas, un fuerte movimiento sindical de masas, suficientes ligas de masas campesinas, suficientes ligas de la juventud comunista, para abrazar a las masas y darles una correcta dirección leninista. ${ }^{11}$

Estas versiones sobre la causalidad comunista atraviesan el mayor espectro de los análisis publicados a lo largo de la historia salvadoreña hasta nuestros días, al considerarla como argumentación sólida y verificable a través de algunas fuentes tanto escritas como testimoniales de la época y la carencia de otros enfoques analíticos que apunten a causas históricas, económicas y étnicas. Daban por sentado que el alzamiento en enero de 1932 tuvo categóricamente motivaciones comunistas y, por lo tanto, la respuesta estatal fue orientada a detenerlas hasta sus últimas consecuencias, al grado de llegar a mantener de manera indefinida a lo largo de 13 años la suspensión de garantías individuales.

En segundo lugar, algunas versiones manifiestan ideas diferentes sobre las causas y la respuesta gubernamental, pero con menos énfasis y reconocimiento por los historiadores, pero expresada por posturas oficiales de aquella época. Por ejemplo, el gobierno militar identificó algunas de las causas del alzamiento como la delincuencia en las zonas rurales del país. Según esta postura, el debilitamiento de las instituciones permitió la proliferación de la violencia social que conllevó a detonar la insurrección acompañada de expresiones violentas, pero sin motivaciones políticas, como si turbas de campesinos armados con palos y machetes que ante la menor oportunidad quisieron hacer justicia por su propia mano y entraran a las casas de los ricos, las saquearan y quemaran, así como generar el terror hacia las clases medias y pudientes de la zona. El propio gobierno alentó esta otra versión y justificó el uso de las armas para "restituir el Estado de derecho" que en la realidad nunca se cumplió, ya que se decretó el Estado de Sitio para enfrentar la revuelta campesina y aniquilar los brotes sociales de inconformidad. 
Considerando que los hechos delictuosos que se desarrollaron en este Departamento y los de La Libertad, Sonsonate, Ahuachapán y Santa Ana, del 19 al 23 del año en curso, justifican la actitud del poder ejecutivo, que en uso de la facultad que le concede el art. 4 de la Ley respectiva, puso al país en Estado de Sitio, para reprimir con la eficacia que el caso requería las demasías de los perturbadores del orden y de la ley; que aunque el gobierno controla por completo todo el país, habiéndose restablecido el orden y el imperio de la Ley, para llevar a cabo las investigaciones de aquellos hechos delictuosos, se hace necesario el mantenimiento del Estado de Sitio. ${ }^{12}$

Una investigación oficial hecha por el periodista salvadoreño Joaquín Méndez, quien realizó un recorrido por las zonas donde se dieron los acontecimientos a menos de un mes, refuerza la idea de que los rebeldes cumplían más una función de delincuentes y saqueadores que otra categoría descriptiva sobre los autores de la insurrección. Méndez presentó una lista en la que se refiere a los daños y perjuicios ocasionados a las familias de acaudalados.

De acuerdo a la lista, la familia Radaelli sufrió los daños mayores por 85 mil colones. Otras pérdidas significativas incluyeron la casa de familia de Mercedes Cáceres por 40, 000 colones y las casas de Lorenzo Ríos y Julia Salavarría por 50, 000. En total Méndez proporciona una lista de treinta propiedades y una pérdida total de más de 300,000 colones. ${ }^{13}$

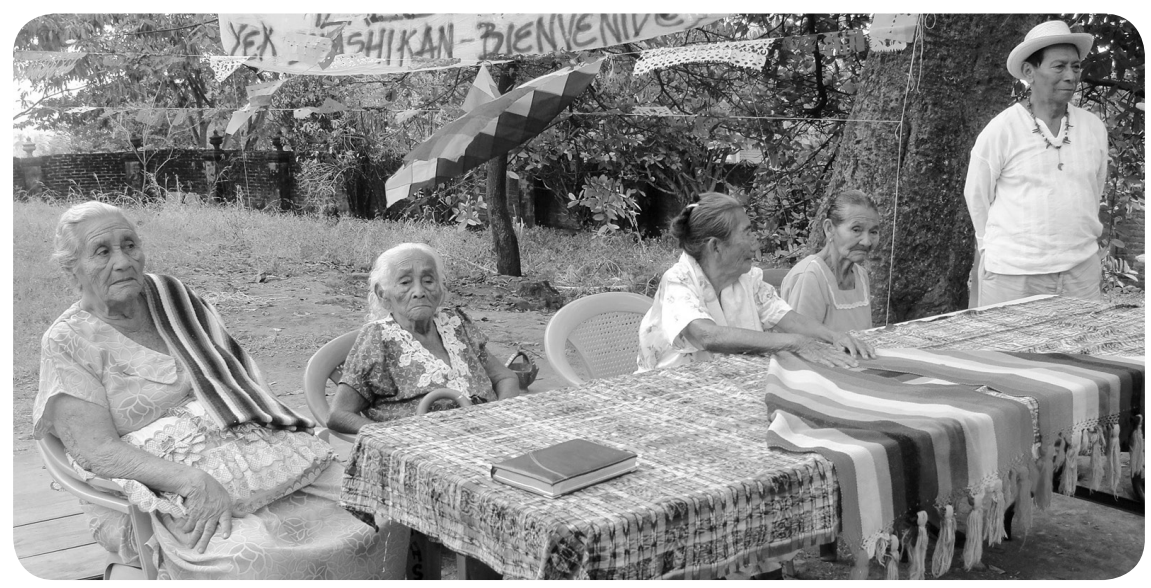


Un tercer enfoque en los análisis sobre el 32 es el que hace énfasis en las causas estructurales, más en la idea de atender causas cualitativas y cultivadas por largos años en el país, lo que permitieron según este enfoque condiciones propicias para la insurrección. En el libro Insurrección no violenta en El Salvador ${ }^{14}$, la autora Patricia Parkman identifica la falta de libertades políticas, la crisis económica y el despojo de tierras a campesinos pobres como las motivaciones del levantamiento. La gran depresión económica mundial de 1929 golpeó aún más la crítica situación de los trabajadores del campo y de las ciudades. Los precios de los productos primarios de consumo, maíz, frijol, café, azúcar, entre otros, decayeron drásticamente. La situación generó un masivo desempleo de mano de obra en las fincas. Parkman analiza los periodos precedentes y subsecuentes para señalar que los 13 años de gobierno militar pulverizaron la libertad, castigaron la disidencia y aniquilaron los descontentos sociales. Ella ubica la respuesta violenta del Estado como un robustecimiento del ejercicio del poder autoritario con el fin de mantener el control y proteger a las clases altas, sobre todo a los terratenientes. Así, al dictador Hernández Martínez se le identifica más como la piedra angular de un sistema de desigualdades generacionales, falta de libertades democráticas y el inicio de un poder militar que se edificó durante la mayor parte del siglo XX en El Salvador.

\begin{abstract}
Martínez no era simplemente el agente de alguno de los sectores de la sociedad salvadoreña. Era un hábil político que trabajó incansablemente dentro de las limitaciones de aquella sociedad para acumular apoyo donde pudiera y neutralizar los focos de oposición real o potencial. Era el clásico dictador latinoamericano que dominaba personalmente a su gobierno. ${ }^{15}$
\end{abstract}

En este mismo renglón de análisis, Jeffrey L. Gould y Aldo LauriaSantiago en su texto 1932, Rebelión en la oscuridad ${ }^{16}$, describen cómo la crisis mundial golpeó con ferocidad a El Salvador, lo generó acumu- lación de rabia, indignación y desesperación de miles de pequeños productores campesinos y colonos que trabajan en las haciendas cafetaleras en el occidente de la nación centroamericana.

Si las condiciones de vida y de trabajo cayeron, habían sido pobres antes de la crisis, para 1930 se habían vuelto intolerables. Los hacendados respondieron a la rápida caída 
de los precios del café con recortes salariales que afectaron tanto a los semi proletarios como a los colonos. ${ }^{17}$

Muy pocos trabajos hasta ahora publicados se refieren a un cuarto enfoque, que es el que propongo como hilo conductor para llegar a definir la represión del 32 como un genocidio cultural y no sólo como masacre o matanza. Se trata de seguir como causalidad determinante de la rebelión el factor étnico social o cultural indígena, las formas propias de organización comunitaria que practicaron los pueblos originarios como elementos sobresalientes que posibilitaron la explosión social de 1932 y, con mayor desarrollo en el análisis, la identificación del concepto de genocidio cultural como la respuesta violenta y represiva del Estado. Si bien en los sucesos del 32 estuvieron presentes elementos que otros autores Ilaman causas tales como las conspiraciones comunistas, la violencia exacerbada, la pobreza y la marginación, no fueron las determinantes para anidar la explosión social de gran envergadura que significó el levantamiento los días 22 y 23 de enero de 1932 en varios Departamentos del occi- dente salvadoreño, y su posterior desarrollo.

En un estudio profundo realizado entre 1975 y 1976, el Doctor jesuita Segundo Montes integró una serie de trabajos de campo y entrevistas con la población que de una u otra forma estuvo relacionada con los sucesos. Tanto indígenas como ladinos fueron consultados con el fin de obtener información primaria para sus análisis. Ese trabajó de tesis doctoral fue el que arrojó mayores luces sobre la participación de los pueblos originarios en los sucesos del 32. Alcanzó su publicación en 1979 con el título El Compadrazgo, una estructura de poder en El Salvador. ${ }^{18}$

Como académico de la Universidad Centroamericana Montes explicó en otro ensayo sobre reflexiones históricas en torno a los levantamientos sociales, que El Salvador de 1932 fue un explosivo movimiento de características étnicas más que comunistas u de otra índole.

Hay que añadir el componente indígena bajo el liderazgo de Ama, quien aunque tuvo conversaciones y posible alianza con los dirigentes del partido comunista en formación..., sin embargo, estaba motivado más bien por su etnia y buscaba los intereses propios de su comunidad indigena. ${ }^{19}$ 
Por su parte, el joven historiador de origen indígena, Julio Leiva rescata esta otra línea de investigación que explica en su libro Los Izalcos, testimonio de un indígena. ${ }^{20}$

Desde un enfoque indígena, lo único que hacían era reclamar sus tierras, las cuales desde nuestra tradición milenaria, son sagradas y sin dueño, pero los ladinos ricos se las habían arrebatado a nuestros ancestros, haciendo uso de la fuerza y el poder. ${ }^{21}$

Con una perspectiva de análisis de largo plazo, las causas fueron cultivándose en décadas pasadas hasta el momento de la decantación y explosión social, potenciada y permitida por un tipo de organización comunitaria, muy politizada en los asuntos públicos, pero con elementos identitarios, culturales y religiosos sólidos, que fueron fundamentales preservar la cohesión de las comunidades, solidez a los pueblos y colectivos originarios entretejidos por la amalgama de las Cofradías, estructuras de corporación en la Colonia, pero marcadas con una tradición ancestral colectiva en la región. En pocos estudios sobre el 32 se hacen mención a determinados aspectos cultuales en este sentido. Si acaso se hacen algunas referencias generales sobre lo étnico, no se llega a desarrollar el término ni se logra identificar los usos y las costumbres, las formas de organización política comunitaria como las Cofradías y la tradición de la lucha en la defensa de su propiedad colectiva de tierras, aguas, saberes y conocimientos locales, todas ellas con alta carga causal del levantamiento aunadas a causas estructurales $y$, en menor grado, a otras determinantes contingentes como la presencia de organizaciones políticas de vanguardia, los comunistas, o la violencia social señalada en las versiones oficiales. Por ejemplo, Gould y Lauria desarroIlan en un apartado de sus estudios a la identificación de una tensión social que cada día cobró mayor dimensión: la conflictividad étnica. Aunque reconocen su existencia, no profundizan en lo determinante para el levantamiento que fue la organización comunitaria de los pueblos de los Departamentos de Sonsonate y la Libertad. Se habla de raza, lengua y mestizaje, pero poco se detallan las bases donde descansa el tejido social indígena de la región, modos de organización política, cultural y religiosa que quedaron de forma secundaria en ese análisis, así como por ejemplo en esta frase a continuación que sobrepone el análisis de clase al análisis de etnia: 
La radicalización de las clases trabajadoras en el Departamento de Ahuachapán tomó su lugar en un complejo tapiz étnico. ${ }^{22}$

Thomas Anderson en El Salvador, 1932 se refiere como efecto $y$ no como causa la discriminación racial, la cual fue un elemento de

persecución durante y después de la represión. Como analizamos antes, las motivaciones para él fueron más ideológicas que étnicas.

Por supuesto que la rebelión de 1932 provocó una fuerte reacción contra la cultura indígena. Hubo una notable disminución en el número de personas que portaban indumentaria indígena, según sus costumbres o hablaban el dialecto. ${ }^{23}$

Tampoco en los estudios referidos a los diversos enfoques sobre las causas de la insurrección se describe, en este sentido, la respuesta violenta del Estado. En ningún caso se identifica con precisión y rigor a ese hecho como una respuesta organizada de la violencia o como un acto de fuerza para la preservación del Estado, ni como un crimen de Estado contra un grupo o colectivo social identificado como sus propias formas de etnicidad, ni siquiera más descriptivamente alude a las características del concepto que en este trabajo de investigación propongo y que desarrollaré en los siguientes apartados de este capítulo, a saber, un genocidio cultural. Este término, a mi juicio, da mayor contenido sustancial a la respuesta represiva del Estado ante la rebelión indígena.

Uno de los pocos y últimos trabajos que asoman elementos de lo étnico con mayor alcance es el ensayo El Salvador 1932, los Cofrades Insurrectos. ${ }^{24}$ Allí, Pablo Benítez llega a la conclusión de que las estructuras corporativas de la Colonia en El Salvador permitieron la preservación de una tradición ancestral de los pueblos indígenas para organizarse en lo que ellos denominan el bien común, fortalecer lazos de identidad y solidaridad y reconocerse como entidades sociales de posesión colectiva de bienes naturales como la tierra y las aguas. Esas estructuras en El Salvador se conocen como Cofradías.

Pasaron a ser espacios propicios para que las comunidades indígenas se organizaran políticamente y consolidaran sus lazos indentitarios y culturales... Con toda seguridad, las cofradías permitieron la consolidación de redes sociales 
muy fuertes, que facilitaron la organización de acciones políticas rebeldes. Son muchos los levantamientos indígenas ocurridos en los siglos XVIII, XIX y XX. ${ }^{25}$

Segundo Montes ya había advertido antes que las causas económicas no fueron las determinantes para la insurrección de Los Izalcos.
Ambos autores, Montes y Benítez en tiempos diferentes coinciden en este planteamiento.

\begin{abstract}
Es preciso notar que los indígenas de la zona, en su mayoría tenían tierras de cultivo, parcelas de mucha fecundidad, y que el colapso del café no deterioró sus condiciones de vida..., por lo que el levantamiento de 1932 tiene un fuerte componente indígena que no era estrictamente material y económico. ${ }^{26}$
\end{abstract}

Estos estudios ya alcanza un nivel de desarrollo mayor que los otros tres enfoques de causalidades en la historia de 1932, pero aún no logran identificar en sus análisis categoriales la respuesta estatal como un acto dirigido a menoscabar, aniquilar y destruir colectivos sociales étnicos, comunidades y pueblos enteros con un idioma propio (el náhuatl), formas organizativas colectivas excepcionales al canon general como son las Cofradías, asambleas comunitarias, regiones étnicas, modos y conocimientos ancestrales sobre el uso de la tierra y las aguas, relación con la naturaleza; estudios complejos que faltaría profundizar para completar el análisis teórico de lo que fue la matanza de miles de personas en 1932. Si bien se contempla el enfoque étnico social en el estudio de Benítez, habría que introducir el desarrollo de lo que he denominado como genocidio cultural de 1932, haciendo énfasis en la respuesta violenta del Estado contra la insurrección, pero dirigida a un tipo de población social nacional, el indígena, sujeto colectivo con identidad propia reprimido por la feroz dictadura dirigida por el General Maximilano Hernández Martínez.

\title{
2. Conceptualizaciones y caracterizaciones sobre la represión del 32
}

La respuesta represiva del gobierno militar de Maximiliano Hernández Martínez al levantamiento indígena de 1932 ha tenido varias interpretaciones conceptuales por parte de los estudiosos de aquellos sucesos. Se le ha denominado básicamente matanza de 1932, asesinato en masa del 32, masacre o etnocidio del 32, pero en cada una 
de las afirmaciones o calificaciones no se han explicado los conceptos. Se han dado por sentados o sobre entendidos, sin detenerse a categorizarlos ni darles contenido teórico explicativo. Hasta nuestros días se habla de la matanza o la masacre, términos que de alguna forma carecen de precisión y abstracción teórico-metodológica para entender los sucesos históricos que significaron la destrucción física y cultural de amplios colectivos sociales, étnicos o religiosos de una nación que en 1932 fue sacudida por la experiencia traumática de desaparecer y aniquilar a miles de personas en pocas semanas con sus consecuencias devastadoras para la cultura originaria y la identidad salvadoreña.

Por ejemplo, el historiador Erik Ching en su ensayo "El Levantamiento de 1932" en el libro El Salvador Historia Mínima ${ }^{27}$, define el accionar del Estado como:

Un horrible y trágico episodio, uno de los peores casos de represión estatal en la historia moderna de América Latina. El asesinato en masa consolidó a los militares en el gobierno, lo cual resultó en 50 años de dictadura militar, el más largo capítulo de ininterrumpido control militar en la historia moderna de Latinoamérica. ${ }^{28}$

Si bien Ching reconoce a la respuesta violenta del Estado como "un hecho trágico" de "asesinato en masa", no alcanza a describir a lo largo de su ensayo los argumentos que sostienen teóricamente una descripción válida para explicar el hecho real de un aniquilamiento de miles de personas en pocos días, ni toma en cuenta las características étnicas ni culturales de la población agredida. Sabemos que allí sucedió un represión y una masacre, "un asesinato en masa", pero no se describen las causas que dan contenido a este hecho de operación estatal de una dictadura como la de Hernández Martínez y, por lo tanto, resulta insuficiente, para categorizar mejor la destrucción física y cultural que sufrieron las poblaciones de la región occidental del país en enero de 1932. Ching, al describir el operativo montado por el gobierno de Martínez y sofocar la rebelión, se refiere como matanza a los acontecimientos de persecución, detención y fusilamiento.

El gobierno nacional comenzó a organizar fuertes columnas de tropas provenientes de los departamentos del centro y del oriente. Solo tomó unos días para juntar a todas las tropas y colocarlas en el tren, por lo que no llegaron a Sonsonate durante la tarde del 25, momento en que las tropas 
ya habían recuperado el control de la región. Pero eso solo fue el comienzo de la matanza. ${ }^{29}$

Pero estas descripciones de "asesinato en masa" y "matanza" sobre los hechos represivos tampoco nos dan un panorama completo y a cabalidad de la compleja respuesta estatal a los sucesos, como si fueran solo respuestas a voluntad de los gobernantes o jefes militares, incluso de las tropas acantonadas en la región donde realizaron sus operaciones para controlar la rebelión, y no como resultado de una estrategia de consolidación y represión para sofocar la rebelión indígena con el uso de la fuerza de las armas del Estado hasta Ilegar a la destrucción física de varios miles de personas, adscritas a una cultura determinada como lo es la población indígena náhuatl pipil. No se identifican a los responsables, quienes formaron parte de las instituciones gubernamentales, del Estado, como actores ejecutores de los crímenes. Lo que hicieron los agentes militares y el propio Maximiliano Hernández Martínez va más allá de un "asesinato" o una "matanza", conceptos que eximen la responsabilidad estatal y deja a los personajes históricos referidos de la época como responsables individuales y no como parte estructural del Estado y su acción punitiva.

El término de matanza, según el Diccionario de la Real Academia Española se define como: "Mortandad de personas ejecutadas en una batalla, asalto, etc." ${ }^{30}$

Si bien Ching es sus argumentaciones explica los hechos claramente determinados por la participación estatal, no los pronuncia como lo que realmente fueron: un genocidio $y$, más concretamente, un genocidio cultural. Por el momento, Ching nos detalla algunos de los elementos que dan contenido al concepto de genocidio que nos irán sirviendo para la argumentación teóricometodológica del concepto de genocidio cultural.

Las unidades militares se desplegaron por el campo matando a campesinos indiscriminadamente. Una de las tácticas militares al llegar a un pueblo era llamar a todos los hombres adultos a que se reportaran a la plaza central para recibir un salvoconducto y evitar ser confundido con un rebelde. Mientras se reunían todos los hombres eran ametrallados en masa. Bandos paramilitares de los pueblos locales que fueron reunidos, recurrieron al campo buscando a cualquiera que mereciera morir. ${ }^{31}$ 


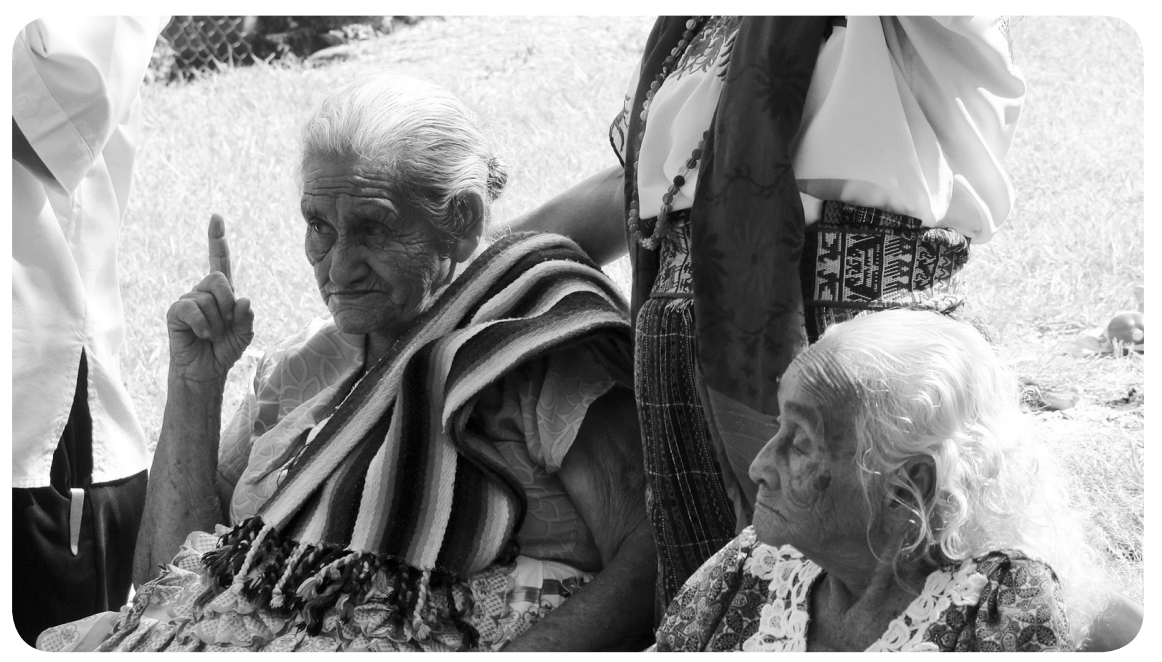

Como hemos analizado en el Diario Oficial de aquel año de 1932, no existe allí una versión oficial de cuántas muertes realmente sumaron los actos represivos del Estado. Lo que tenemos son testimonios, escritos, memorias y análisis de estudiosos sobre ellos, que dan algunas aproximaciones y que reflejan suficientemente la participación de los órganos de seguridad del Estado en los hechos, que determinaron la existencia de aquel resultado dramático en la historia del siglo XX en El Salvador. Dice Ching:

No existe manera de determinar el número de personas muertas. Nadie hizo cuenta y los archivos no dicen nada al respecto. Todo lo que se tiene son varias descripciones de testigos y algunas de las fotografías de los cadáveres tirados en las calles y movilizados en carretas para ser colocados en fosas comunes. Certeramente se puede decir que varios miles de personas fueron asesinadas. ${ }^{32}$

Por su parte, Patricia Parkman en su libro Insurrección no violenta en El Salvador se refiere como "ma- sacre" y califica como indiscriminada la respuesta de los militares a los indígenas insurrectos.

Pero los militares se desquitaron con ejecuciones masivas de campesinos que cobraron miles de vidas en las áreas afectadas... Esta masacre indiscriminada sin duda distanció a muchos salvadoreños. ${ }^{33}$ 
De hecho, la respuesta a la insurrección en el occidente salvadoreño en 1932 fue una masacre sin límites. Pero este último concepto tampoco nos precisa el hecho en su completa acepción. Una masacre, según el diccionario de la Real Academia Española se refiere:

A una matanza de personas, por lo general indefensas, producida por un ataque armado o causa parecida. ${ }^{34}$

Para el caso tratado, Parkman también abstrae, con el uso del término "masacre", la responsabilidad estatal. Ciertamente es una matanza de personas con un ataque armado, pero también lo fue por orden directa de Maximiliano Hernández
Martínez y asumida por los hombres de armas, ni más ni menos que de un ejército constituido, el cual además asumió las directrices del gobernante durante y después de los ataques.

La Secretaria a mi cargo se vio en la imperiosa necesidad de aumentar sus efectivos a fin de reforzar debidamente los cuarteles y poder restablecer la tranquilidad interior, imponer el orden y extirpar radicalmente aquellas manifestaciones antipatrióticas, malsanas y peligrosas. ${ }^{35}$

Según Thomas Anderson también Hernández Martínez promovió y organizó la Guardia Civil, estructura paramilitar que actuó en la matanza de indígenas bajo órdenes del Ejército. "Martínez organizó la guardia en Santa Ana en forma de Guardia Civil." ${ }^{36}$
Una masacre también puede ser también realiza por civiles, pero en este caso de la masacre de 1932 no fue el caso. Se trató de una masacre realizada por actores estatales, el ejército y grupos paramilitares (Guardia Civil) como describe la misma analista Patricia Parkman.

Menos de dos meses después de que Martínez asumiera la presidencia, el conflicto a fuego lento en el campo, que tanto había mortificado a sus predecesores, finalmente hizo crisis. Solamente algunas de las comunidades predominantemente indígenas del occidente tomaron las armas y las tropas del gobierno restablecieron el control en aquella región en tres días. ${ }^{37}$

Por lo tanto, lo que queremos destacar con estos diálogos entre diversos autores y también de declaraciones oficiales, es que ninguno de ellos hace énfasis sobre conceptualizar las ejecuciones 
del gobierno militar de Hernández Martínez. Solo se refieren a ellos sin darle profundidad teórica a sus argumentaciones de cómo nombrar la respuesta represiva del Estado salvadoreño para aplastar la rebelión.

Los historiadores Héctor Lindo, Erik Ching y Rafael Lara Martínez se refieren en su libro Recordando 1932 también como una matanza a las acciones militares contra los insurrectos. El capítulo 1 del texto referido, incluso lleva el título "El levantamiento y la matanza de $1932^{\prime \prime 38}$ y a lo largo de él los análisis manifestados hablan solo como la matanza del 32. El siguiente texto, pese a que describe la acción y ejecución estatal represiva del gobierno dictatorial, sobre todo después de la rebelión, no los conceptualizan.

Los militares sometieron a las zonas rurales del occidente a una brutal represalia. Unidades militares fuertemente armadas se desplazaron a gran velocidad por la densa población de la campiña, asesinando indiscriminadas a campesinos. Una de las tácticas más utilizadas para aligerar la matanza fue dar la orden para que la población masculina de los cantones vecinos se congregara en la plaza de un pueblo con el pretexto de entregarles salvoconductos; los soldados entonces los alineaban y los ametrallaban en masa. ${ }^{39}$

Estos elementos identifican que no sólo fue una matanza, ni una masacre, que fueron eso, pero concretamente por responsabilidad estatal, ausente también en los análisis.

La muerte de miles de personas, indígenas en su inmensa mayoría, fue dándose en todo el occidente de El Salvador después de la insurrección. Una vez controlados los territorios por los militares, los aniquilamientos fueron sumándose hasta alcanzar cifras que se calculan entre 10 y 30 mil personas.

En la medida que se repetían las masacres pueblo tras pueblo en todo el occidente, los cadáveres empezaron a apilarse a las orillas de los caminos y en montones dispersos. En lo posible, los soldados o los ciudadanos de la localidad los enterraban en fosas comunes, pero el número de muertos sobrepasó las capacidades de los pobladores y muchos cadáveres quedaron al descubierto durante días. ${ }^{40}$

Esta gran matanza como la califican los autores es conceptual- mente compartida por Thomas Anderson, quien logra también percibir 
los elementos que dan contenido sustancial al término de genocidio por la responsabilidad de los agentes del Estado, pero no alcanza al igual que nos otros a desarrollar esta tesis y llegar a este resultado, puesto que su estudio radica en otras coordenadas de interpretación causal, a saber, la conspiración comunista.

La matanza que se llevó acabo es cosa que no puede sorprender. En los alrededores de Izalco empezó una redada de sospechosos. Como a excepción de los dirigentes, la mayor parte de los rebeldes no se podía identificar con facilidad. Se establecieron las más arbitrarias clasificaciones. A todos los que se les encontraba portando machetes se les consideraba culpables, todos aquellos que tenían fuertes rasgos de raza indígena, o que vestían los sucios trajes de manta de los campesinos, eran culpables. ${ }^{41}$

Por otro lado, autores como Jeffrey L. Gould y Aldo Lauria comienzan a utilizar el término de genocidio para señalar los acontecimientos que van desde enero hasta marzo de 1932. Clasifican los hechos en tres etapas. La primera se refiere a las secuelas de la derrota de la insurrección, la segunda la que trata sobre los acontecimientos después del aplastamiento de la insurrección y la tercera sobre los mismos acontecimientos pero en mayor escala hacia un área geográfica más extensa. Etapas en las cuales se registran masacres en la región occidental del país.

\begin{abstract}
El 24 de enero los militares comenzaron su campaña la cual duró más de un mes. Para aproximarse mejor a las distintas causas y métodos de las masacres, es analíticamente útil un desglose entre las distintas etapas de la represión, aun cuando la realidad histórica estuviese más matizada. ${ }^{42}$
\end{abstract}

Argumentan que en la primera etapa se cristalizó un tipo de genocidio haciendo alusión por primera vez a la Convención de las Naciones Unidas sobre la Prevención y el Castigo de Genocidio citado por el investigador estadounidense Eric D. Weitz en su texto Un siglo de genocidio: utopías de raza y nación ${ }^{43}$ donde los autores enfatizan la intencionalidad: "La intención de destruir en todo o en parte una raza, nacionalidad, religión o etnia." 44 Además, citan de igual forma a un caso donde se llevaron a cabo investigaciones sobre el genocidio de 1980 en Guatemala y que Ilegaron a la determinación de que no hubo intención de genocidio, sino que hubo un "tipo" de genocidio 
realizado por parte del ejército guatemalteco contra población indígena. Con estos dos principios jurídicos, intención y hecho consumado de genocidio, argumentan su planteamiento de nombrar para el caso de 1932 en El Salvador como una "forma de genocidio". Al describirlo con este concepto por primera vez se establece claramente en la historiografía existente sobre los acontecimientos del 32. Sin embargo, los autores no están claros sobre si existen "tipos o formas de genocidio" o si solo se debe nombrar el genocidio para describir la acción represiva del gobierno salvadoreño de entonces. Al comparar ambas experiencias, la guatemalteca de los años 80 con más de 100 mil muertes a manos del ejército y 600 comunidades afectadas en dos años, y la salvadoreña del 32 con alrededor de 30 mil muertes en la zona occidental del país en menos de un mes, llegan a la conclusión de que las diferencias suelen ser marcadas y por tal motivo Ilaman al caso de El Salvador como "una forma de genocidio".

A pesar de las desigualdades, existe suficiente evidencia en cuanto a que las masacres salvadoreñas escalaron en una forma de genocidio. No hay duda de que el 'régimen militar de Martínez alentó los asesinatos en masa con órdenes directas, o de que el racismo condicionó esas órdenes o su ejecución. ${ }^{45}$

Para ellos, "el tipo de genocidio" tiene que ver más con la raza y lo étnico anclándose en la Convención de las Naciones Unidas, en lo expresado en lo concerniente a un grupo indígena en cuestión y tanto por intención como por hecho consumado.

El motivo principal del régimen, aplastar la insurrección e infundir miedo y terror en los corazones y en las mentes de los pobres del campo, se fusionó con una intención enmarcada por el racismo y sobre determinada por el odio de clases, con el resultado de que se mató a miles de personas en una forma de genocidio. ${ }^{46}$

No obstante estas argumentaciones con base a lineamientos jurídico-políticos internacionales como los derechos humanos, los autores no precisan en sus investigaciones la ausencia de "formas de genocidio", y no dan cuenta que sólo existe el genocidio como tal en la jurisdicción universal de los preceptos humanos. Por lo tanto, su planteamiento de "una forma o tipo de genocidio" es ambiguo y poco claro sobre cómo describir los acontecimientos que marcaron 
profundamente la historia salvadoreña de la primera mitad del siglo $\mathrm{XX}$, con alcances y reminiscencias hasta nuestra actualidad, ¿O es genocidio o es un tipo de genocidio? Entonces queda la pregunta ¿La respuesta del Estado dirigido por el presidente Maximiliano Hernández Martínez a la rebelión de 1932 fue un acto de genocidio? A mi juicio no solo fue un genocidio, sino un genocidio cultural reconocido en la jurisdicción universal de los derechos humanos, porque existen elementos en la documentación oficial, en los testimonios y en la historiografía del caso sobre la época que dan contenido a este planteamiento.

Por otro lado, algunos análisis interpretativos acuñan el término de etnocidio para caracterizar a la matanza de los pueblos indígenas de la región occidente del país durante y después de la rebelión. Lo dan como un hecho y lo toman por sentado. El historiador Rafael
Lara Martínez propone un texto controvertido titulado Política de la Cultura del Martinato ${ }^{47}$ que busca describir la política cultural del régimen de Hernández Martínez y la aceptación abierta o velada de la intelectualidad salvadoreña de la época en un contexto de la ausencia de legitimidad por los hechos represivos del 32. Para el análisis que nos concentra retomaré algunas frases y reflexiones donde Lara Martínez acuña el término de etnocidio. Al criticar a los historiadores Jeffrey Gold y Aldo Lauria en su texto 1932 Rebelión en la Oscuridad ${ }^{48}$ y a Erik Ching en Recordando 1932 la Matanza ${ }^{49}$, por no referirse ni incluir los documentos primarios del oficialismo y del propio Hernández Martínez en sus argumentaciones sobre la masacre del 32 y el rol desempeñado por los intelectuales y artistas ante su política cultural, Rafael Lara pronuncia que la matanza de 1932 fue un etnocidio.

\section{Ni siquiera los trabajos más acabados sobre el crimen pri- mordial que se le atribuía a su régimen, la matanza o etno- cidio de enero de 1932 en el occidente del país, se atrevían a explorar los expedientes primarios del implicado. ${ }^{50}$}

Pero aquí Lara no explica por qué fue un etnocidio, pese a que nos invita a investigar la versión oficial de los hechos. Pareciera que el concepto es tomado como un hecho, sin incluso ir a las fuentes primarias oficiales o testimoniales, ni en los análisis de otros estudios que se refieran al término etnocidio.
Lo da por sentado. El autor vuelve a utilizar el término de etnocidio en su ensayo titulado "Armas y Letras", incluido en este mismo texto que se refiere al estudio de una producción literaria de la época: El Ateneo. En un pequeño resumen de este breve texto, el historiador explica en qué consiste su reflexión: 
"Armas y Letras" estudia la producción cultural de una institución salvadoreña: el Ateneo de El Salvador... Indaga la contribución de los Generales Maximiliano Hernández Martínez y José Tomás Calderón. Ambos personajes se vinculan con la supresión de una revuelta y etnocidio que ocurren en el occidente del país en enero de 1932. ${ }^{51}$

De allí en adelante deja de usar el concepto y asume que todo lector reconoce los hechos del 32 como un etnocidio. El autor, sin proponérselo, abre una paradoja. Mientras cree que la versión oficial radicó en una vehemente política indigenista, exaltando los valores de ésta, promoviendo los derechos de los pueblos indígenas y la visión multiculturalista para afianzar la identidad nacional, por el otro, califica de etnocidio la represión en el occidente salvadoreño. ¿Es posible sostener ambas diatribas, contradictorias entre sí? El etnocidio y la política indigenista se interponen y excluyen. O hubo un etnocidio, entendido como el exterminio de amplios sectores sociales con características culturales propias como los indígenas y una promoción hueca y sin fundamente de una política manipula de características indigenistas, o no existió tal exterminio de población autóctona porque la política del régimen era acorde a las necesidades culturales de los pueblos originarios. Lara se encuentra encerrado en esta paradoja y no logra resolverla.

Si hipotéticamente Lara Martínez explicara en el libro que estamos analizando correctamente lo que es un etnocidio, es decir, como un genocidio contra la población indígena, destacando la participación y responsabilidad del Estado salvadoreño de enfocar la represión contra los pueblos en sus formas propias culturales, políticas y sociales, su análisis apuntarían a cuestionar centralmente la política cultural del régimen como incoherente, puesto que mientras se destruyó una cultural dada (etnocidio) se generó también una política cultural indigenista para exaltar una visión paternalista, estatista y de asimilación cultural.

Lara nos propone ir a las fuentes primarias, pero sus fuentes utilizadas en este estudio son parciales. Sólo nos detalla las fuentes oficiales y deja de lado las fuentes primarias de las víctimas del etnocidio, de los sujetos indígenas y su cultura. Carece de fuentes primordiales de cómo los indígenas directamente veían la política indigenista del gobierno militar, si la vinculación "armas y letras" fue aceptada por los propios pueblos originarios. No hay entrevistas primarias, ni citas en torno a los derechos culturales, ni la política de promoción y preservación de la cultura ancestral, ni tampoco el reparto y restitución 
de tierras comunales que nunca hubo, ni el reconocimiento a las formas tradicionales de organización política que se manifestó en el marco de las Cofradías. Todo esto se encuentra ausente y él alude más bien a la política cultural desde el poder estatal y la participación de los intelectuales -que por cierto no eran indígenas- en la exaltación de rasgos autóctonos, superpuestos, para consolidar una identidad nacional como producto del mestizaje y el encuentro de "dos mundo", el ladino y el indígena.

Con el mismo rigor que nos propone Lara Martínez sobre el uso de las fuentes primarias, también él mismo debería sostener un proceso metódico para la utilización de los conceptos, como el de etnocidio, síntesis de determinaciones históricas, políticas o culturales a partir de esas mismas fuentes primarias a las que alude.

Con esta investigación exhaustiva de una revista literaria de El Salvador en absoluto pretendo legitimar la presidencia del general Maximiliano Hernández Martínez ante la opinión historiográfica en curso. Menos aún, anhelo eximirlo de su responsabilidad por el etnocidio (vuelve a repetirlo). La contribución apunta hacia un objetivo muy distinto: el rigor historiográfico. ${ }^{52}$

...Pero para la historiografía los conceptos también son determinantes, claves y de vital importancia, sobre todo para los estudios críticos y las argumentaciones críticas sobre los hechos del pasado. Y el etnocidio, como concepto empleado en los estudios sobre los escritos de la historia de 1932 es necesario explicarlo para entender lo que sucedió a partir de la historia de las ideas generada desde entonces.

Lo mismo pasa en su obra Balsamera bajo la guerra fría, El Salvador 1932, historia intelectual de un etnocidio. ${ }^{53} \mathrm{En}$ él, vuelve a usar el término sin explicarlo, aunque en este caso sí se analiza con mayor profundidad la causalidad étnica sobre los acontecimientos de la época tratada. Entre algunos de sus análisis el historiador concluye: "La represión cobra un sesgo de etnocidio o, si se prefiere, de limpieza étnica." ${ }^{54}$

Los únicos autores que han analizado el término de etnocidio y llegan a concluir que el concepto es inconsistente para describir la represión oficial del 32 son Erik Ching y Virginia Tilley en su ensayo sobre "Indígenas, militares y la rebelión de 1932 en El Salvador", el cual forma parte del libro Las masas, la matanza y el martinato en El Salvador. ${ }^{55}$ Dicen los autores: 
Los hallazgos que se presentan en este ensayo demuestran que la versión convencional de los acontecimientos de 1932, al menos en aquellos aspectos que se refieren al fin de la identidad indígena, tiene muchas cualidades propias de una leyenda. Todavía quedan muchas preguntas sin contestar, en particular el por qué la presunción de un etnocidio deliberado adquirió tanta fuerza en las décadas siguientes, aunque estas deberán esperar el resultado de futuras investigaciones, este escrito está pensado como el primer paso hacia una compresión más sólida sobre cómo se ha manifestado la identidad étnica, durante el siglo XX, en El Salvador. ${ }^{56}$

Los autores sostienen que la versión de etnocidio es vaga $y$, por lo tanto, poco fiable para utilizarla, en tanto que según la idea de et- nocidio que ellos mismos tienen es la de la prohibición del uso de sus formas tradicionales de vida, vestimenta, cultura y lengua.

Todas las fuentes oculares de la violencia, en sus primeros momentos, describen asesinatos a mansalva en muchos lugares del campo y fusilamiento, a primera vista de campesinos indígenas, pero ningún autor hace referencia a la prohibición explícita del uso de la vestimenta indígena o de expresiones de identidad étnica en general, y no se ha encontrado evidencia documental de semejante orden o política. ${ }^{57}$

Pero en este estudio, los autores no desarrollan argumentaciones de contenido para identificar los elementos del etnocidio, pese a que reconocen que hubo asesinatos a mansalva y fusilamientos, pero no indican por quién fue hecho, elemento fundamental ya que quien comete etnocidios son sólo los Estados o miembros de los Estados y no los particulares, tal y como detalla la legislación universal de los derechos humanos y que se explicará en el apartado 3 de este artículo. Tampoco los autores detallan qué entienden por etnocidio, ni dan una definición como tal, ni citan autores que den características propias del etnocidio. Como los analistas anteriores dan por sentado que lo que ellos entienden por etnocidio, o cualquier concepto para describir la represión del 32, es una convención aceptada por todos. Ching y Tilley, entonces, no dan cuenta que el concepto de etnocidio está ampliamente reconocido y estipulado por el orden jurídico internacional en su acepción más precisa y que forma parte del régimen de los 
derechos humanos. Para ambos autores pareciera en sus análisis que el etnocidio es la desaparición o asimilación de una cultura, que efectivamente es en parte es así, pero no es solo eso, sino también lo es el exterminio masivo de indígenas por agentes estatales. Sin embargo, los autores solo se refieren al primer aspecto de la asimilación cultural y argumentan con base a ello que la matanza del 32 no fue un etnocidio, pues no encuentran tal evidencia de asimilación, ni en las fuentes primarias ni en los análisis sobre el caso a partir del censo nacional. Con estudios del censo de 1940 llegan a la conclusión que la población indígena de la región donde se registraron las represiones más severas, no decayeron los índices de población indígena, sino, por el contrario, crecieron. Argumentan:

Luego de tomar los datos del nacimiento de cada 5 años de 1900 a 1950 en los departamentos de Sonsonate y Ahuachapán, el centro del territorio de la matanza... Los resultados que se presentan en la tabla 1 son reveladores. No se observa ni una caída brusca, ni siquiera leve, en el porcentaje de nacimientos indígenas después de 1932...Los registros de nacimientos revelan, de forma inesperada, tasas de indígenas relativamente altas. ${ }^{58}$

\section{Y sostienen:}

Los cambios en las tasas de nacimiento no indican tampoco que estuvieron vinculados con los acontecimientos de 1932. Pareciera que la versión del etnocidio en 1932 está lejos de constituirse en una versión precisa de la asimilación indígena. ${ }^{59}$

Sin embargo, el censo de $1930^{60}$ fechado hasta el mes de mayo, revela datos importantes. En el gráfico titulado "Población de la República Clasificada por Sexo, Nacionalidad, Domicilio, Raza, Instrucción, Propietarios y No Propietarios" se exponen la cantidad de población considerada ciudadana salvadoreña e indica que suman para ese año 1, 420, 968 salvadoreños de los cuales dice el mismo censo existen para el año de 1930, la cantidad de 79, 573 indios. Esto significa, que si la población indígena, con mayor presencia en el occidente salvadoreño, en los departamentos de Sonsonate y Ahuachapán, alcanzó hasta 30 mil muertes en los sucesos del año de 1932, estamos hablando que desapareció físicamente alrededor del 37. 70 por ciento. Son datos reveladores que muestran lo que 
pasó con la población originaria en apenas pocos meses de los acontecimientos. Una pulverización de la comunidad indígena y con graves consecuencias políticas, sociales y culturales para El Salvador. Este cálculo contrasta categóricamente con las conclusiones de Ching y Tilley.

Por otro lado, el análisis del concepto de etnocidio no reside en aspectos cuantitativos, aunque nos revelen datos importantes como la cantidad de personas asesinadas en masa en 1932, sino en aspecto cualitativos, en este caso de que el Estado salvadoreño dirigido por Hernández Martínez ordenó fusila- mientos en masa y fueron masacrados miles de personas, mayoritariamente indígenas, como todos los autores analizados aquí coindicen. Pero Ching y Tilley concluyen que el etnocidio depende de registros cuantitativos y dejan de lado lo fundamental, lo que se refiere al exterminio de un sujeto colectivo, la comunidad indígena, la masa reprimida con una identidad propia. No se trata de si desaparece una comunidad, pueblo o individuo indígena, sino cómo esta comunidad, pueblo o individuo es objeto de agresión y alcanza a llegar hasta ser exterminada, en este caso, bajo orden y acción del Estado.

\section{El concepto de genocidio cultural}

En principio debemos de explicar el concepto de genocidio, que precede teóricamente al genocidio cultural, con el fin de hilar el desarrollo teórico argumentativo que nos lleve a describir a éste último.
El genocidio, según la Convención de 1951 para la prevención y la sanción del delito genocidio aprobado por la Organización de las Naciones Unidas (ONU) es descrito como:

Cualquiera de los actos mencionados a continuación, perpetrados con la intención de destruir total o parcialmente a un grupo nacional, étnico, racial o religioso como tal: matanza de miembros de un grupo; lesión grave a la integridad física o mental de los miembros del grupo; sometimiento intencional del grupo a condiciones de existencia que hayan de acarrear su destrucción física, total o parcial; medidas destinadas a impedir el nacimiento en el seno del grupo; traslado por fuerza de niños del grupo a otro grupo." 61

Esta declaración es asumida por todos los miembros de la ONU al reconocer que: 
En todos los periodos de la historia el genocidio ha infligido grandes pérdidas a la humanidad... (y) que es un flagelo tan odioso que necesita de la cooperación internacional... (y) las partes contratantes confirman que el genocidio, ya sea cometido en tiempos de paz o en tiempos de guerra, es un delito de derecho internacional que ellos se comprometen a prevenir y a sancionar. ${ }^{\prime 62}$

Así, el genocidio como concepto alcanza un nivel de desarrollo importante a tal punto de ser aceptado por todos los países del mundo, gobiernos y pueblos, instituciones y ciudadanos, lo cual representa que es un concepto de reconocimiento convencional y un derecho internacional. Como delito, el genocidio es definido en la Convención de 1968 sobre la imprescriptibilidad de los crímenes de guerra y de los crímenes de lesa humanidad como imprescriptible, es decir, que se puede investigar y sancionar a los responsables aún si esos actos no constituyen una violación del derecho interno del país donde fueron realizados, en cualquier momento, pasado o presente, vivos o muertos los responsables. En el artículo 1 de dicha convención se enlistan los crímenes que son imprescriptibles, cualquiera que sea la fecha en que se hayan cometido y dentro de ellos destaca el genocidio:

El delito de Genocidio definido en la Convención de 1948 para la prevención y la sanción del delito de genocidio, aun si estos actos no constituyen una violación del derecho interno donde fueron cometidos. ${ }^{63}$

A partir de esta definición del genocidio se deriva el de genocidio cultural a veces explicado con menor fuerza como etnocidio. Éste se ancla en la destrucción física y a la vez la destrucción de lo que da identidad a los colectivos humanos tal como idioma, cultura, formas de organización, usos y costumbres. Una primera aproximación del genocidio cultural se encuentra en el documento presentado en 2002 sobre los crímenes que sanciona la Corte Penal Internacional (CPI) como institución integrante de la ONU.

Los actos cometidos con la intención de impedir a los miembros de un grupo utilizar su idioma, practicar su religión o realizar las actividades culturales propias del grupo tendientes a desaparecerlos, o asimilarlos por otros grupos. ${ }^{64}$ 
Se trata de un acto premeditado o acto consumado en destruir un colectivo humano y con ello sus expresiones culturales, el idioma, la religión, usos y costumbres, sea nacional, étnico o religioso, en función de su origen. El genocidio cultural es un término en pleno desarrollo. Por ejemplo, ya existe como concepto jurídico-político y varios países del mundo lo han incorpora- do en sus leyes y normas generales como lo hizo recientemente la República del Ecuador el 6 de abril del 2009 y publicada en el Diario del Registro Oficial el 27 de abril del mismo año en concordancia con las Convenciones Internacionales de Genocidio, Crímenes de lesa humanidad y Corte Penal Internacional, y su adecuación al Código Penal del país sudamericano.

Ley reformatoria al código penal que tipifica el delito de genocidio y etnocidio. Artículo 1 Agréguese antes del artículo 441 del Código Penal, dentro del título VI del libro II, el siguiente capítulo innumerado. Capítulo de los delitos de genocidio, genocidio cultural y etnocidio. ${ }^{65}$

No obstante, el genocidio cultural aún no se encuentra plenamente integrado a todos los países miembros de la ONU y por lo tanto a la legislación universal de los derechos humanos, al no ser todavía aprobado por la mayoría calificada de los Estados y Naciones miembros de la ONU, pero como concepto descriptivo sobre el ejercicio del poder de un Estado cuenta con plena fuerza categorial para las ciencias sociales, la filosofía y el derecho como ejemplifica el Estatuto de Roma que da base conceptual a la CPI. En este sentido, el

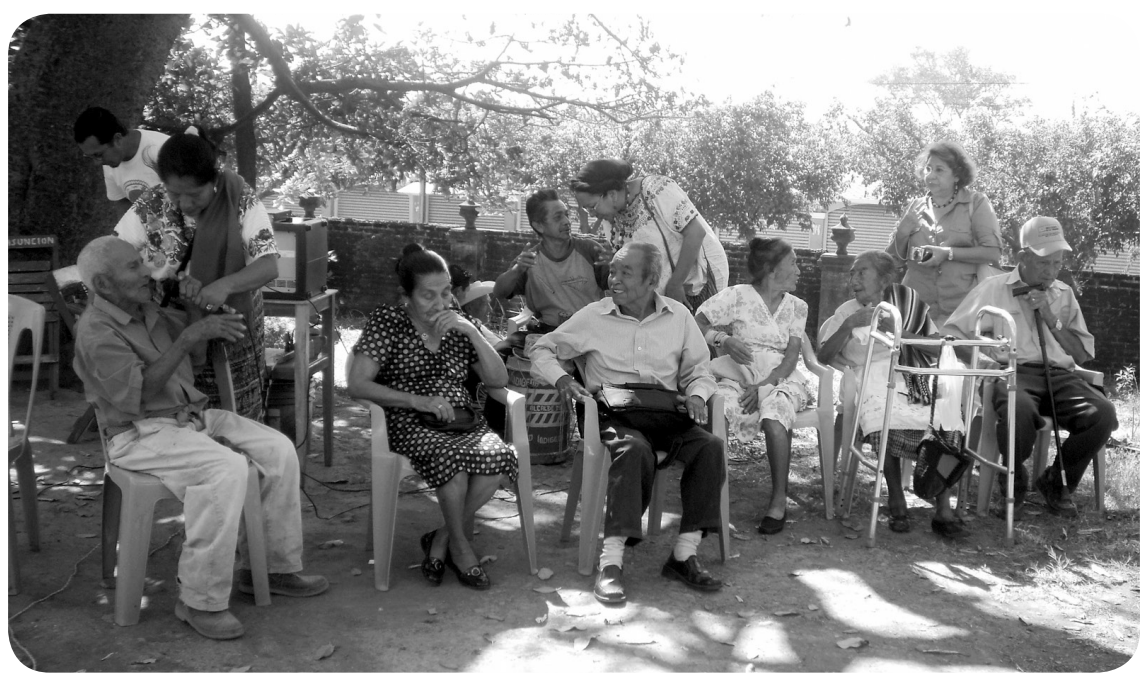


genocidio cultural cuenta con una historia y una tradición de exigencia por parte de amplios sectores sociales, pueblos étnicos, juristas y filósofos que lo defienden como un derecho por tipificarse y hacerse útil al régimen internacional de los derechos del hombre, sobre todo al registrarse acciones estatales, o de miembros de los Estados ---que atentaron contra los principios culturales, étnicos y religiosos--- y con ello dan contenido material a las leyes en la marco de la existencia de los Estados modernos, de cualquier signo ideológico o político. El genocidio cultural se integra ya en los debates sobre inclusión normativa y sobre crímenes de lesa humanidad. Se incorpora este término en la definición de genocidio utilizada en el Estatuto de Roma que da espíritu y forma a la Corte Penal Internacional, siempre y cuando el "genocidio cultural" comparta alguno o todos los cinco principios de competencia, a saber: Matanza de miembros del grupo, lesión grave a la integridad física y mental de los miembros del grupo, sometimiento intencional del grupo a condiciones de existencia que hayan de acarrear su destrucción física, total o parcial; medidas destinadas a impedir nacimientos en el seno del grupo; traslado por la fuerza de niños del grupo a otro grupo.

Se deduce, entonces, que el "genocidio cultural" tiene su correlativa efectividad, como definición derivada, al cumplirse uno o alguno de estos elementos que definen al genocidio tal como se explica en el derecho internacional consuetudinario. En 1985, el Relator Especial designado por la Subcomisión de Prevención de Discriminaciones y Protección a las Minorías de la Organización de las Naciones Unidas (ONU), Benjamín Whitaker, se refirió al genocidio cultural como:

Todo acto premeditado y cometido con la intención de destruir el idioma, la religión o la cultura de un grupo nacional, racial o religioso por razón de origen nacional o racial o de las creencias religiosas de sus miembros, actos tales como: la prohibición de emplear el idioma en las relaciones cotidianas o en las escuelas o la prohibición de imprimir o de difundir publicaciones redactadas en el idioma del grupo y la destrucción de las bibliotecas, los museos, las escuelas, los monumentos históricos, los lugares de culto u otras instituciones y de los objetos culturales del grupo o la prohibición de usarlos. ${ }^{66}$

Se advierten así métodos de acción u omisión por parte de los gobiernos o Estados hacia grupos nacionales, étnicos o religiosos. A la par del concepto de genocidio cultural surge, en el ámbito de los 
pueblos indígenas de América, el reconocimiento y la definición más local de etnocidio como mecanismo de "desarraigo cultural". Los dos conceptos indican la misma acción del Estado orientada a la destrucción de colectivos sociales étnicos no sólo físicamente, sino también a su cultura en todas sus manifestaciones. El término de etnocidio ha sido mayormente utilizado por parte de colectivos sociales en Latinoamérica. Es un término utilizado al momento de la defensa de los derechos de los pueblos y culturas originarias al denunciar el peligro que existe sobre el "derecho a la diferencia" como "muerte a la diferencia" de aquellas lenguas, saberes, vestimentas, usos, costumbres y culturas humanas. Así como lo indica el historiador Pablo Dávalos, al comentar la ley nacional ecuatoriana denominada Tipificación de los Delitos de Genocidio y Etnocidio que aprobó la Comisión Legislativa en abril de 2009, concluye:

Diferencias radicales porque son irreductibles, porque perderlas implica la muerte cultural como preámbulo de la muerte social y hasta física. ${ }^{67}$

La propia Convención para la Prevención y Sanción del Delito de Genocidio en conformidad con la CPI incluye del mismo modo el caso del genocidio cultural al referirse a la destrucción de un grupo étnico en tres aspectos: 1) Matanza de miembros del grupo, 2) Lesión grave a la integridad física o mental de los miembros del grupo, 3) Sometimiento intencional del grupo a condiciones de existencia que hayan de acarrear su destrucción física, total o parcial, medidas destinadas a impedir los nacimientos en el seno del grupo.

El etnocidio, como concepto amplio no necesariamente adquiere una actitud violenta, sino, también puede ser una actitud más "optimista" con el fin de reconvertir a la población objetivo, o fuera del canon cultural impuesto a lo considerado por quien o quienes lo imponen. Se trata de una transformación a semejanza de la cultura que hegemoniza, obligando a un grupo social a despojarse de su identidad para civilizarse o adquirir los modelos predominantes por relaciones históricas de dominación.

No obstante, una nueva legislación que acuerpen las naciones del mundo, que incluya un desarrollo de la autonomía jurídica del genocidio cultural podría profundizar las consecuencias de ley para que sin duda se permita investigar hechos históricos que alumbren actos bárbaros y crímenes del pasado en la senda de la justicia, con el apoyo de otros instrumentos de derecho internacional como el documento presentado en 1973 sobre los prin- 


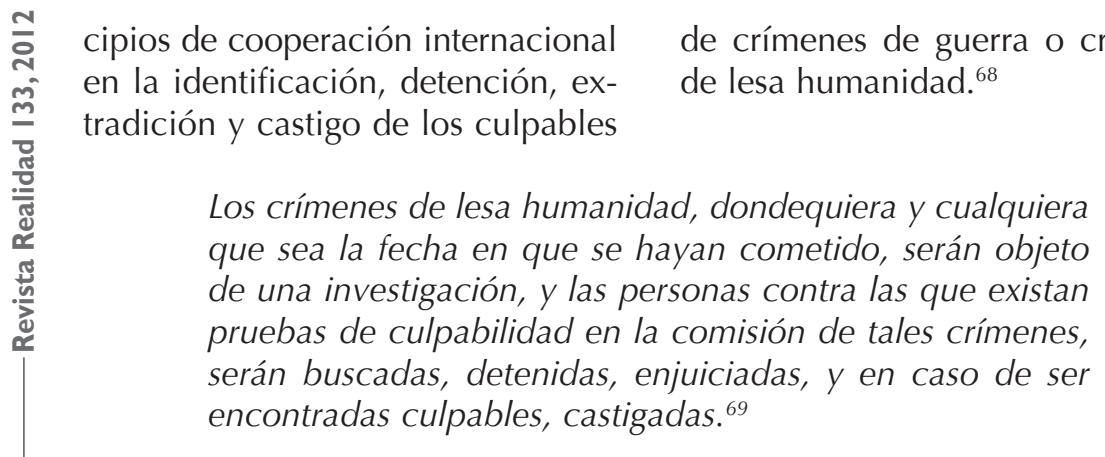

El Estatuto de Roma, que fue adoptado el 17 de julio de 1998 por la ONU, incluye en el primer

párrafo de su Preámbulo la siguiente frase:

Conscientes de que todos los pueblos están unidos por estrechos lazos y sus culturas configuran un patrimonio común, y observando con preocupación que este delicado mosaico puede romperse en cualquier momento, teniendo presente que, en este siglo, millones de niños, mujeres y hombres han sido víctimas de atrocidades que desafían la imaginación y conmueven profundamente la conciencia de la humanidad... ${ }^{70}$

De tal forma que la CPI, que comenzó a funcionar el 1 de julio de 2002, se ha convertido en una de las principales instituciones del sistema internacional que avanza en el reconocimiento expreso sobre los crímenes contra los pueblos originarios y da la pauta para que se consolide un régimen de derecho respetado por los Estados miembros.

En el ámbito legal, el Estatuto se ha convertido en el marco mínimo aceptable para la investigación y judialización de crímenes internacionales. Desde la tipificación de estos crímenes, pasando por los mecanismos de cooperación internacional, la participación de las víctimas y el derecho de defensa. ${ }^{71}$

En la CPI priva el principio de complementariedad de jurisdicción y cooperación global que permite ir consolidando una forma para encausar los crímenes cometidos contra poblaciones con identidad específica. Es así que en el mismo Estatuto de Roma se tipifica el delito de Apartheid, como una conducta que se reconoce como crimen in- 
ternacional a partir de la política segregacionista durante el régimen de dominación de la minoría blanca en Sudáfrica.

Actos inhumanos cometidos en el contexto de un régimen institucionalizado de opresión y dominación de un grupo racial sobre uno o más grupos raciales y con la intención de mantener este régimen. ${ }^{72}$

Otro antecedente importante a nivel internacional es la creación del Estatuto del Tribunal Internacional para la Ex-Yugoslavia. ${ }^{73}$ Después de la desintegración de una nación pluriétnica y la guerra de los Balcanes, con crímenes horrendos y deleznables, la comunidad internacional creó esta instancia con el fin de investigarlos y procesar a los responsables. Se trató de una competencia en razón de materia (ratione materiae). Un tribunal que tiene competencia para juzgar los siguientes actos que se relacionan con el genocidio y con la destrucción del habitad cultural de po- blaciones humanas. Violaciones a las leyes o prácticas de guerra. De acuerdo al Estatuto, tales violaciones comprenden, sin que esto impida reconocerse otras, las siguientes: la destrucción sin motivo de ciudades y pueblos, o la devastación no justificada por exigencias militares. La toma, destrucción o daño deliberado de edificios consagrados a la religión, a la beneficencia y a la enseñanza, a las artes y a las ciencias, a los monumentos históricos, a las obras de arte y a las obras de carácter científico y enfatiza los actos que serán castigados:

El genocidio, la colaboración para la comisión de genocidio, la incitación directa y pública a cometer genocidio, la tentativa de genocidio y la complicidad en el genocidio. ${ }^{74}$

A partir de esta descripción podemos concluir que el desarrollo de la jurisprudencia alcanza un nivel sin precedentes y que a medida que vaya desenvolviéndose lograremos más alcances en ideas y conceptos útiles para la historiografía, la historia de las ideas, y otras disciplinas a partir también de las propias prácticas con las que cuentan pueblos y comunidades en su reclamo por el derecho a la diferencia y la tipificación del genocidio cultural. Para el caso de El Salvador ahora notamos con un nuevo enfoque sobre los sucesos de 1932. 


\section{Reflexión filosófica sobre el genocidio cultural}

El genocidio cultural como concepto cuenta con una matriz filosófica que data de la época del nacimiento de la modernidad, es decir, su raíz nace de siglos atrás y se definen en tanto entendemos este último término:

Un proceso de carácter global, de una realidad distinta a las precedentes etapas históricas, en la que lo económico, social, político y cultural se relacionan, se interpretan, avanzan a ritmos desiguales hasta terminar por configurar la moderna sociedad burguesa, el capitalismo y una nueva forma de organización política, el Estado Nación. ${ }^{75}$

Sus orígenes, entonces, se circunscriben en la época del Estado moderno y la naciente concepción de los derechos del hombre y del ciudadano aprobada en la Asamblea Nacional Constituyente francesa del 26 de agosto de 1789, al definir los derechos personales y colectivos como universales. Se trata de un documento precursor de los derechos humanos. Por tanto, su efectiva correlación a los derechos derivados a lo largo de la historia hasta nuestros días deviene en un proceso continuo y sugestivo para nuevos conceptos e ideas que hagan prevalecer los derechos del hombre universales. De allí que los conceptos genocidio, crímenes de lesa humanidad y genocidio cultural, en el marco de esta tradición, enfrentados y relacionados a los acontecimientos, hechos y sucesos que se han ido presentando en el devenir histórico, son el resultado del desenvolvimiento y el desarrollo de las ideas, concepciones

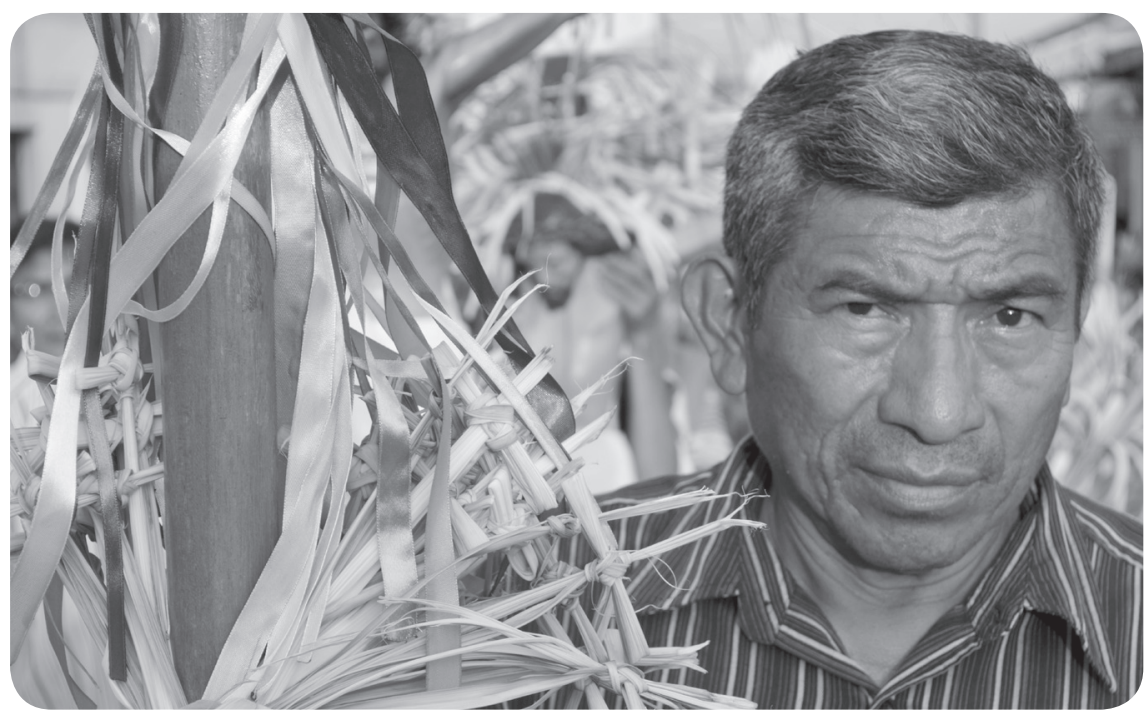


y debates en torno a los derechos humanos. Pero estos términos nacen a la luz de los sucesos que marcan jurisprudencia universal, es decir, aquellos hechos que perturban, sacuden y engendran la violación de los derechos fundamentales y que en la época de la modernidad no son pocos ni excepcionales. Algunos filósofos y pensadores, incluso, analizan ese periodo de la humanidad Ilamado modernidad y llegan a la conclusión de que es una etapa de violación sistemática de los derechos del hombre y el ciudadano en nombre de nuevos mitos creados, dentro de ellos, el mito del progreso. En su obra Hacia una crítica de la razón mítica, el laberinto de la modernidad ${ }^{76}$, Franz Hinkelammert recorre las fases de este proceso histórico y concluye que se trata de otra etapa donde se renuevan los mitos, pero ahora de la sociedad burguesa que impone sus ideas sobre el mundo y actúa en consecuencia para forzarlas como hechos consumados.

El gran mito que sustenta la modernidad hasta hoy --- aunque ya se está quebrando--- es el mito del progreso. Surge con la modernidad y le da de su alma: su alma mítica... Progreso que desde hace tiempo se está transformando en un monstruo... destruye la vida humana, por eso se transforma en un monstruo. ${ }^{77}$

De igual manera, otros filósofos, al analizar la época de la modernidad, concluyen que ésta se revierte contra el ser humano y que todas las promesas de libertad, fraternidad e igualdad, bases de los derechos humanos, se recluyen en su antítesis atrapada en el mito del progreso que actúa contra la humanidad.

El progreso técnico que se transforma en dominio y destrucción de la naturaleza por el hombre, no se equipara con el desarrollo humano, sino por el contrario, produce una continua pérdida de libertad de hombres y mujeres. ${ }^{78}$

Y el Estado moderno, símbolo de la civilización occidental, deviene en la máquina destinada para su ejecución y realización. Una maquila sacrificial.

La filosofía del progreso fue convertida en una religión estatal, que ha logrado seducir a la clase política. ${ }^{79}$ 
El Estado deviene en otro mito de la sociedad burguesa, un mito genial, que se define cómo imperio de la ley. Siguiendo a Hinkelam- mert, en otra acepción sobre los mitos de la modernidad, el mito del poder.

La institucionalización impone reglas de comportamiento, que en la modernidad son leyes. Pero como estas reglas no se cumplen espontáneamente debido a la contingencia del mundo, la institución presupone el ejercicio del poder. Este poder tiene que imponerse; lo que hace, en última instancia, por la amenaza de muerte. ${ }^{80}$

Ante la totalidad de la máquina sacrificial, la única huida parece ser otra totalidad, la de la muerte.
Pero nadie quiere morir o seguir el sendero hacia la huida fatal.

La institución resulta ser administración de la muerte en función del orden. Esta función no cambia, aunque cambie históricamente el orden institucional que se impone. Siempre es última instancia de la imposición del orden y no se puede no imponer un orden: institución es administración de la muerte. ${ }^{81}$

El ejemplo más perturbador de las conciencias en el siglo $\mathrm{XX}$ y que mayor análisis tuvo fue la experiencia del nazismo y el Estado totalitario de Hitler en la década de los 30 y Segunda Guerra Mundial. Allí se manifestó el alcance del poder del Estado en nombre de la modernidad, el progreso y la ciencia, dilapidando paradójicamente

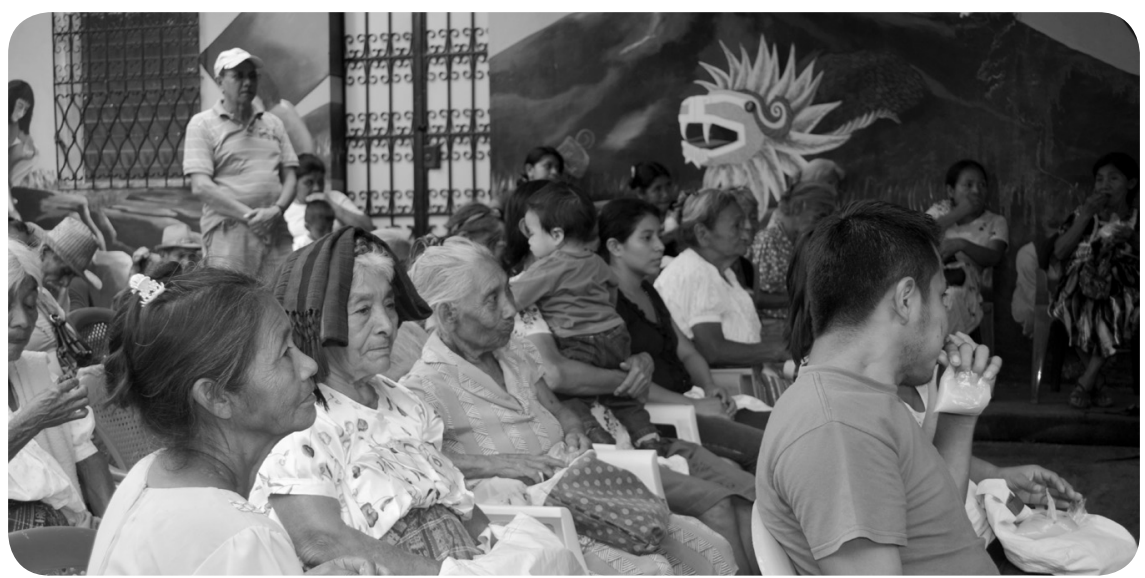


los derechos humanos también engendrados por la modernidad como negatividad y esperanza frente al mito del poder.

Pero así como la misma modernidad engendró la barbarie, el genocidio, engendró su negatividad crítica con los juicios de Neuremberg al investigar, procesar y deslindar responsabilidades sobre estos horrores del pasado y llegar a la producción de ideas y conceptos que permitieron un juicio sobre los mitos generales. Es en Nuremberg que el concepto de genocidio alcanza su completa aceptación por el régimen internacional de los derechos humanos y una esperanza del principio general de los derechos del hombre proclamados en 1789.

\section{El 20 de noviembre de 1945, el proceso de los criminales}

de guerra se abrió en el Palacio de Justicia de Nuremberg... de este modo comenzó el mayor proceso de la historia. ${ }^{82}$

El análisis del genocidio en ese juicio fue determinante para instaurar los principios de Crímenes contra la Humanidad, entre ellos el genocidio, y en esa coyuntura histórica se orientaron sobre todo a los efectos contra los judíos, considerados un grupo nacional. Estos crímenes fueron:

El asesinato en masa, el exterminio, genocidio, la reducción a la esclavitud, o cualquier otro trato inhumano y degradante por motivos políticos, raciales o religiosos. ${ }^{83}$

Las conclusiones generales de estos procesos que sumaron 403 audiencias fueron la materia prima para la redacción del principio judice del genocidio, aceptado por los países integrantes de la Orga- nización de las Naciones Unidas (ONU) que en su documento inicial reconocen no solo al nazismo como autor del genocidio, sino como la existencia de genocidios en la historia moderna:

En todos los periodos de la historia el genocidio ha infligido grandes pérdidas a la humanidad... (y) que es un flagelo tan odioso que necesita de la cooperación internacional.... ${ }^{84}$

Esto también conllevó a la determinación que en la historia moderna de la humanidad existieron genocidios sin reparar, sin investigar ni juzgar. Por lo tanto, se marcó jurisprudencia y el inicio de investigaciones pretéritas y presentes sobre los crímenes de lesa humanidad, entre ellos el genocidio, y también una nueva etapa del uso convencional 
del término que permite una mayor aceptación de él en estudios de las diversas y muchas disciplinas existentes.

También comienza a la luz de sucesos en la historia la conceptualización del genocidio cultural como un derecho derivado. Otro de los mitos de la modernidad es la del proceso emancipatorio del atraso y la ignorancia de los pueblos y culturas que deberían civilizarse a imagen y semejanza de las culturas civilizadas occidentales. Esta idea hegemónica hasta nuestros días ubica a aquél diferente, no occidental, como alguien o algo que tiene que civilizarse, modernizarse, hacerse hombre ciudadano de un Estado civilizado, de un Estado sacrificial que calcula sus acciones y determinación. Hinkelammert habla al respecto:

El mito presente de una sociedad calculadora, de la eficacia, calcula la eficacia del sacrificio humano, aunque de manera completamente arbitraria y sin ningún argumento de fondo. Sociedades anteriores sacrificaron a los Dioses con igual arbitrariedad, pero con un mito del poder específicamente diferente. ${ }^{85}$

El mito del poder actual es la destrucción atropellada o la subsunción de culturas y comunidades por Estados modernos. En nombre de la civilización, la modernidad y el progreso, amplios colectivos humanos sucumbieron por la fuerza o fueron absorbidos por los cánones impuestos hasta desaparecer como cultura. Una dinámica homogeneizadora del mundo que provoca la muerte de la diversidad cultural. Y este hecho comenzó con el proceso de colonización mundializada desde occidente, el cual se nombró descubrimiento de América.

Ese primer choque del siglo XVI fue total entre lo antiguo y lo moderno. En ese momento clave se enfrentaron concepciones del mundo y del universo (Occidente y Mesoamérica)... en esta génesis de lo moderno y universal, 1492, nació el etnocidio y el genocidio. Ninguna obra civilizatoria está exenta de su labor destructora. La modernidad nace con la colonización como corolario. Con el sobre entendido de que el Occidente cristiano tenía la superioridad. ${ }^{86}$

Se trata de una suerte de etnocentrismo que equivale a la asimilación violenta o impositiva de una cultura o civilización por otra, echando mano de los mecanismos coercitivos y coactivos de los
Estados modernos y sus órganos de seguridad que detentan el monopolio estatal de la violencia, independientemente de su orden político o ideológico. 
Casi por todas partes, las naciones retrasadas se encontraron frente a la equivalencia: modernización igual a occidentalización y el problema de lo moderno fue confrontado al de la identidad nacional, al de las fronteras geográficas e imaginarios del Otro reconstruyendo su mundo. ${ }^{87}$

La existencia y acción práctica de los pueblos indígenas en la historia de la modernidad en América se presenta, entonces, como actos de resistencia ante el intento modernizador que deviene en oposición, lucha y antagonismo. Con ello, los pueblos y etnias promovieron un discurso abierto como pueblos libres, pueblos originarios, pueblos de raíces milenarias, pueblos con ecología de saberes, es decir, como pueblos con una cultural basada en la diversidad y no en la homogeneidad. Esto último ha sido condenado, invisibilizado, desarraigado, perseguido $y$, en muchos casos, destruido, adquiriendo el nivel de genocidio cultural o etnocidio.

José Javier Esparza, en una reflexión filosófica habla del etnocidio contra los pueblos, su mecánica y sus consecuencias de lo que él mismo Ilama el colonialismo cultural ${ }^{88}$, identifica varios elementos que nutren el concepto de genocidio cultural, un ejercicio de buena conciencia, ejercido por el bien del salvaje y concluye que sus resulta- dos son tanto más atroces que los de la exterminación física. Así surge el etnocentrismo como sinónimo de autocentrismo cultural definido en 1906 por W.G. Summer ${ }^{89}$, en el sentido que da una concepción del mundo según la cual el grupo al que se pertenece es el centro de todo y los demás grupos a la periferia deben pensarse en referencia al primero. Es un planteamiento que permite vislumbrar jerarquías en las concepciones y creencias de un grupo social sobre otro u otros que dan la pauta para escalonar y jerarquizar hacia abajo a comunidades y pueblos. Y se manifiesta como elogio de lo propio y desprecio de lo ajeno. El etnocentrismo, por ende, se expresa en la corriente hegemonizadora del mundo natural y social, provocando la desaparición de la diversidad cultural y la concepción destructora de la naturaleza como objeto de satisfactores y no como ambiente de vida equilibrada de complejas especies animales, flora y colectivos humanos, como analiza el filósofo mexicano radicado en Francia, Fernando Matamoros.

Si para Europa es el signo de su supremacía y resplandor, para el mundo indígena periférico es destrucción, miseria y muerte. ${ }^{90}$ 
De allí podemos desgranar otros conceptos que enaltecen sin fundamentos la idea de lo inferior como la Alterofobia, o el odio a lo Otro, al canon general practicado en regímenes dictatoriales e imperios. Pero ese Otro tiene identidad, distinta al primero, por lo cual lo hace diverso en igualdad a aquél. A la lógica del hegemon se escapa la mirada del Otro, de los Otros. El rostro del Otro, ese próximo al que Levinas $^{91}$ apunta como carnalidad sensible, una especie de Yo psíqui$\mathrm{co}$, es un víctima de esta máquina devoradora de la modernidad. El Estado que la representa, insaciable y perenne, destruye esa noción del Otro en su sacrificialidad inmanente y punzante. La crítica de Zizek ${ }^{92}$ a Levinas radica en que ese Otro, despojado de todo logos y conciencia, deja de ser Otro sujeto, y cuando se deja de ser Otro sujeto, queda la sumisión como los capturados en los campos de concentración nazi, que serían lo mismo que los secuestrados en los campos de concentración de las dictaduras militares en Latinoamérica o los fusilados en masa como en 1932 en El Salvador o los negros en Sudáfrica durante el Aparthied, o los pueblos indígenas desarraigados, aculturizados o sometidos en la conquista de América. El resultado, el hombre sometido, el Homo Sacer al que se refiere Hinkelammert, producto final del proceso de sacrificialidad de la máquina automatizada, que se abona como parte constitutiva del engranaje complejo de todo el sistema. Entonces emerge como dispositivo del mecanismo complejo de coerción y coacción que se afirma en totalidad, la totalidad estatal, a lo que nadie ni nada escapa. Un Estado represor con instituciones violentas pero legales y no necesariamente legítimas. Esa dinámica de sacrificialidad, no obstante, topa con la mirada del Otro, quien para la máquina no tiene sentido, puesto que deja de ser un sujeto. Quizá aquí Zizek no repara en que ese Otro de Levinas, en su peor condición de des-subjetivación, que momentáneamente deja de ser Otro, para ser igual a uno, al civilizado, nunca deja de serlo en su origen, sólo intrínseca e individualmente, sino que apela a los Otros que como él es corresponsable de la víctima. Y en esa condición de vida suspendida que le impone la máquina sacrificial, resiste a ella y alcanza en un momento dado su condición frente a los Otros y de allí surge la ética compartida con los Otros en condición extrema de sacrificio, bajo la condición de un genocidio cultural o muerte a la diferencia. Algunos filósofos reconocen en el Otro, la diferencia y la dignidad, como aquello de resiste a ser negado, destruido o aniquilado. Se trata de un reconocimiento al Otro, su vida, su cultura, su dignidad. Es, en todo caso, una respuesta a la modernidad y a su eje sacrificial a partir de la responsabilidad con los Otros, una ética compartida con los otros, la ética de la vida, la búsqueda de la vida en comunidad 
de la que habla el filósofo Enrique Dussel, quien se refiere, retomando el planteamiento de Lévinas sobre el Otro, a aquél que no es igual a mí, diferente en corporeidad y cultura, pero comparte la dignidad, la ética y la vida como un todo. Reconoce en los Otros la posibilidad de la ética y la llama ética de la vida como antítesis del Alterofobia y el genocidio cultural.

El punto de partida es la víctima, el Otro, pero no simplemente como otra persona igual en la comunidad... sino ética e inevitablemente como Otro en algún aspecto negado, oprimido y afectado, excluido. ${ }^{93}$

Para los hombres y las mujeres en esa condición durante el nazismo o durante la masacre de 1932 en El Salvador u otro ejemplo de genocidios y genocidios culturales dados, la esperanza de escape, liberación o emancipación estuvo viva y se confirma como memoria histórica de los que en condición de hombres sometidos Homo Sacer, sobrevivieron y contaron y recrearon el horror padecido con el objetivo de que nunca más volviera a pasar. Ese nunca más fue convertido en denuncia por esos Otros, ética y políticamente corresponsables en la búsqueda de dar contenido a los conceptos de genocidio y genocidio cultural para que estos nunca más se repitan. Por eso, resulta la necesidad de nombrar con un preciso concepto ---los hechos de horror, pretéritos, presentes y futuros--- de genocidio y de genocidio cultural como los extremos del Estado moderno, el progreso y la civilización. Se trata del reconocimiento del Otro en calidad de víctima, de excluido, reprimido, marginado, masacrado. Por ejemplo, los indígenas masacrados en 1932 en El Salvador como lo que verdaderamente son: historia, cultura, comunidad, pueblos originarios. Genocidio y genocidio cultural son términos que se explican a través de los hechos y acontecimientos de la historia y la lucha de las ideas por nombrar a la barbarie.

Cuando el etnocentrismo se potencia genera el Odio a lo Otro, a lo diferente de uno mismo. Tras de sí se esconde una insatisfacción cultural que es, dice José Esparza: "Pérdida del auto concepto de la comunidad étnica." ${ }^{94} \mathrm{Y}$ que consiste en la repudiación y en la asimilación.

La repudiación consiste en que la relación de un grupo con el otro se interpreta según el esquema dualista naturalezal cultura. La sociedad civilizada juzga a la sociedad salvaje como inferior, infra-humana... Esta dominación no excluye la violencia física o la aniquilación de una raza (genocidio), 
tampoco excluye el etnocidio, pero aquí este se produce como consecuencia directa del ejercicio de la dominación violenta. ${ }^{95}$

Por otra parte, la asimilación es una expresión concreta pero más negación de la diferencia mediante la asimilación a sí mismo.

sutil de la alterofobia. Consiste en la

El Otro es idéntico a uno... Se trata de un etnocidio con buena conciencia... que actúa en dos movimientos consecutivos. A) la aculturación que genera una heterocultura y la asimilación efectiva que es el etnocidio propiamente $\operatorname{dicho}^{96}$

La aculturación es el conjunto de contactos e interacciones recíprocas entre culturas. En el caso de una cultura autóctona frente a una cultura conquistadora, aunque se ha visto resistencia, se procesa un germen de cultura sincrética, lo que permite o da paso a la creación de agentes que promueven la aculturación generando una heterocultura como lo define el antropólogo L. Poirier:

Procesos sostenidos de asimilación completa, desaparición definitiva de la cultura original, que acepta abierta o por dominación los valores del otro dominador. ${ }^{97}$

De allí que el etnocidio se explica como la muerte a la diferencia. Comparte una idea entorno al Otro, adopta una actitud violenta o una actitud "optimista", según convenga. Si los Otros son "malos", entonces son susceptibles a ser mejorados, modelados y reconvertirlos en "buenos". Se trata, bajo ese discurso, de hacer un bien al salvaje, al Otro reconocido como inferior, violento, ignorante, pobre, sucio. Esta posición es una manifestación de la universalización de un prototipo de lo único e indivisible. Dice Esparza:

Esta actitud se inscribe en el axioma de la unidad de la humanidad, en la idea del hombre universal y abstracto, en el arquetípico del hombre moderno genérico que basa la unidad de la especie en un dato zoológico, con lo que la cultura es reconocida a la naturaleza: es una especie de regresión anticultural. ${ }^{98}$ 
Esto constituye la matriz ideológica del etnocidio, las ideas que guían su accionar. Se trata del hombre occidental moderno que deviene en modelo planetario. El etnocidio o genocidio cultural comenzó de hecho en América cuando los españoles impusieron la guerra de conquista. De allí el horror que alimenta la historia de los pueblos originarios del continente, y la muestra del camino atropellado de la Ilamada modernidad. Se trata de un apocalipsis o destrucción total anunciado y realizado en territorio americano. Pero no solo la conquista, sino ese devenir que se desplegó en la espacialidad y tem- poralidades del continente y que reflejó sus monstruosidades en ciertos momentos. Así se dio cause a la historia de la modernidad en este hemisferio, y que podemos resumir como el apocalipsis que indican el uso de la fuerza de los Estados modernos para los pueblos y culturas originarias de América.

El filósofo Franz Hinkelammert analiza el relato y otras interpretaciones que se dan torno a El Apocalipsis en las Sagradas Escrituras. ${ }^{99}$ Llega la conclusión de que el relato de Juan podría mostrar la existencia en proceso de las colectividades humanas como los pueblos indios:

Habla (n) de un futuro en cuanto está contenido en su presente, por eso, al hablar del futuro, habla a la vez de su presente. ${ }^{100}$

Así, El Apocalipsis de Hinkelammert abre una puerta del futuro en el presente. El humano está situado en la historia, es decir, en una espacialidad y en una temporalidad, como considera Xavier Zubiri. ${ }^{101}$ Pero ese presente histórico humanizado es un fluir instantáneo y fugaz, que se ancla en el pasado como memoria y abre posibilidades para el futuro que no está dado, inconsistente y sólo imaginado. Se trata de una historia de colectividades, y estas colectivida- des más activas han sido los pueblos originarios. En el relato de Juan en la Biblia se escuchan las trompetas anunciado lo que viene, pero lo que viene no lo conocemos, puede ser muerte y destrucción, pero también puede ser la vida y la reconstrucción, entonces lo que se anuncia en las trompetas es un spin, un giro que anuncia lo que puede venir a partir de lo que se hace y se tiene en el presente. Franz Hinkelammert dice al respecto:

En la primera parte principal se abren los sellos y suenan las trompetas. La historia pasa por catástrofes, pero su destino queda oscuro. Sin embargo, aparece el grito: hasta cuándo, Señor. Con el sonido de la sexta y de la séptima trompeta se anuncia ahora la solución de este 'hasta cuándo'. ${ }^{102}$ 
Eso que queda al aire como la respuesta inconclusa es un panorama de incertidumbre, por eso el humano moderno se enfrenta a la incertidumbre del futuro porque no lo conoce y apenas lo puede adivinar en el presente, pero lo puede hacer dibujándose un panorama conmovedor o desolado, en esa dos vías generales, sobre todo a partir de su historia plegada de destrucción del Otro y negación de la alteridad, es decir, de sujetos sociales colectivos como son los pueblos de la América indígena. Lo contrario a la vida cultural es la catástrofe. El filósofo alemán Walter Benjamin describe este horror en la metáfora de la huida sin destino, la metáfora del ángel destructor de la modernidad que arrastra y atropella todo lo que ve a su paso, volteando atrás y horrorizándose de lo que hace. En las Tesis de Filosofía de la Historia ${ }^{103}$, Bejamin describe en su planteamiento titulado como IX:

Hay un cuadro de Klee que se llama Angelus Novus. En él se representa a un ángel que parece como si estuviese a punto de alejarse de algo que le tiene pasmado. Sus ojos están desmesuradamente abiertos, la boca abierta y extendidas las alas. Y este deberá ser el aspecto del ángel de la historia. Ha vuelto el rostro hacia el pasado. Donde a nosotros se nos manifiesta una cadena de datos, él ve una catástrofe única que amontona incansablemente ruina sobre ruina, arrojándolas a sus pies. Bien quisiera él detenerse, despertar a los muertos y recomponer lo despedazado. Pero desde el paraíso sopla un huracán que se ha enredado en sus alas y que es tan fuerte que el ángel ya no puede cerrarlas. Este huracán le empuja irrefrenablemente hacia el futuro, al cual da la espalda, mientras que los montones de ruinas crecen ante él hasta el cielo. Ese huracán es lo que nosotros llamamos progreso. ${ }^{104}$

Pero no todo está perdido, también puede haber esperanza de que esto cambie, no desde el ángel destructor, sino desde las víctimas, desde los agredidos, desde los vilipendiados como han sido los pueblos indígenas. Ernest Bloch ${ }^{105}$ llamaría en términos positivos a esto El Principio Esperanza, como lo que viene construido en el presente, condensación del pasado y posibilidad inminente de un futuro mejor. Es la suerte del futuro echada al aire, que se revelará. De ese principio esperanza es evocado el principio de los derechos del hombre de 1789 en los anales de la historia. 
Es el misterio que subyace a la historia y que define su desenlace, el destino de la historia. ${ }^{106}$

Pero en el caso del Apocalipsis, el destino es un tránsito violento, un mal necesario para la redención de la humanidad. Entonces está claro que lo mejor llegará pero ¿a costa de qué? Es la pregunta clave de todo el texto que analiza el filósofo Franz Hinkelammert. La humanidad y su diversidad cultural tendrán que atravesar el camino de un futuro trágico que se respira y vive, como toda paradoja, anunciando su horizonte de salvación. Morir para vivir, contradicción aparente y discurso reiterado de los pueblos indígenas. Morimos hoy para vivir mañana, dicen los indígenas del estado de Chiapas en México.

Nosotros nacimos de la noche. En ella vivimos. Moriremos en ella. Pero la luz será mañana para los más, para todos aquellos que hoy lloran la noche, para quienes se niega el día, para quienes es regalo la muerte, para quienes está prohibida la vida. Para todos la luz. Para todos todo. Para nosotros el dolor y la angustia, para nosotros la alegre rebeldía, para nosotros el futuro negado, para nosotros la dignidad insurrecta. Para nosotros nada. ${ }^{107}$

Se torna en principio un desaliento de lo que viene pues es amenazador, pero se resiste con la esperanza de algo mejor. En un primer momento es: el principio de agresividad inmanente a la modernidad occidental, que se manifiesta en código naturalista del ser viviente que actúa con violencia por instinto de sobrevivencia, por su propio bien y de los suyos, que se puede manifestar como rebelión, de vuelta evocando el grito de libertad, igualdad y fraternidad de la Revolución francesa. Entonces es violencia legitimada por el sentido del bien para la transformación. Es Estado de rebelión como considera el filósofo Dussel. ¿Pero bien de quién o para quién? Para la humanidad misma que lejos de sacrificar este horizonte de horror, sacrifica su existencia, en aras de un futuro promisorio.

La justificación de la guerra de conquista de los pueblos originarios, la justificación de la masacre como mal necesario para salvar a la sociedad de cánceres sociales como el "comunismo", tal y como se dio en 1932 en El Salvador que desde el poder formal se instruyeron acciones estatales violentas contra la población local originaria, fue la antítesis de la historia inicial de la modernidad, los derechos del hombre y del ciudadano y del derecho a la rebelión. Para evitarla se podría optar por el desvanecimiento del tiempo en uno solo. Es 
tiempo pasado-presente-futuro, en uno solo, que como Adorno sentenció cuando fue testigo del horror nazi y apeló a esos tiempos de la memoria-acción-provenir contra la barbarie: "Después de Autzwich no se podrá escribir más poesía."108

Pero el aún-no de Ernest Bloch es la guía esperanzadora de la humanidad que busca quitarle el sentido trágico a la séptima trompeta que anuncia el final de los tiempos, el genocidio cultural, y marca un horizonte de posibilidades para el mañana que con la lámpara perenne de la memoria histórica (que por cierto es cultivada por los pueblos indígenas) nos dice a través del presente que puede evitarse el cataclismo que se anuncia: el genocidio cultural.

¿En la dialéctica destrucciónconstrucción que sugiere El Apocalipsis de Hinkelammert pueden existir otras posibilidades que lo eviten? El relato de Juan es de su

\section{Notas}

1 El presente artículo es una síntesis del primer capítulo que compone la tesis preparada para la facultad de postgrados y la Maestría en Filosofía Iberoamericana: "El Genocidio Cultural de 1932, Narrativas y Memorias de la Represión".

* Master en Filosofía Iberoamericana de la Universidad Centroamericana José Simeón Cañas (UCA) y estudiante del Doctorado en Filosofía. Actualmente se desempeña como tiempo, pero nos enseña a oler el nuestro y de allí buscar la respuesta a esta pregunta y hacerse esta otra ¿Pervivirán los pueblos indígenas para enseñarnos el buen vivir con la naturaleza, respetarla, amarla, cuidarla como lo han hecho pese al genocidio cultural? El texto Apocalipsis abre estas posibilidades de reflexión y la manera de nombrar el futuro en el presente sin caer en relativismos ni clarividencias. Es un libro que a mi juicio nos enseña a leer nuestro presente con la luz de la memoria para los caminos por recorrer, que esa luz que viene de siglos atrás, de los primeros moradores de la historia cultural de nuestro continente, de esos pueblos indígenas que resisten la barbarie: el genocidio cultural.

Nota: En la siguiente edición de Realidad aparecerá la segunda parte en forma de artículo titulado El Genocidio Cultural de 1932, estudios teóricos y testimoniales.

docente de la Maestría en Métodos y Técnicas de Investigación Científica de la Universidad de El Salvador (UES) y es corresponsal de la cadena televisiva Telesur.

2 ONU. Convención para la Prevención y la Sanción del Delito de Genocidio. "Artículo II de Las Partes Contratantes.” 12 de enero de 1951. Pág. 84. En http://www.un.org/ es/comun/docs/?symbol=A/ RES/260III 
3 FUENTES, Héctor y otros. Recordando 1932: la matanza, Roque Dalton y la política de la memoria histórica. Pág. 20. Ed. FLACSO, El Salvador, 2010.

4 DALTON, Roque. El Salvador: Monografía. Ed. UCA Editores, El Salvador, 2002.

5 DALTON, Roque. Miguel Mármol, Los sucesos de 1932 en El Salvador. Ed. UCA Editores, El Salvador, 2007.

6 Opus cit. Pág. 115.

7 ANDERSON, Thomas. El Salvador 1932, los sucesos políticos de 1932. Pág. 7. Ed. EDUCA, Costa Rica, 1979.

8 Ídem. Pág. 10.

9 HERNÁNDEZ, Maximiliano. "Manifiesto del Presidente de la República y Comandante General del Ejército al Pueblo Salvadoreño.” Diario Oficial. 23 de enero de 1932. Tomo 112, Núm. 18, Pág. 121. San Salvador, 1932.

10 Ídem.

11 BURO del Secretariado de El Caribe. "Reporte del Comité Ejecutivo del Comintern sobre El Salvador 1932." Archivo del Estado ruso para la historia social y política. Fuente 495 , apartado 119 , inventario 2 , pág. 6. Moscú, 1932.

12 VILLACORTA, J. H. "Informe de la Presidencia de la Asamblea Legislativa." Diario Oficial. 18 de febrero de 1932. Tomo 112, Núm. 41. Pág. 277. San Salvador, 1932.

13 FUENTES, Héctor y otros. Recordando 1932: la matanza, Roque Dalton y la política de la memoria histórica, pág. 47. Ed. FLACSO, El Salvador, 2010.

14 PARKMAN, Patricia. Insurrección no Violenta en El Salvador. Ed. Concultura, El Salvador, 2006.

15 Ídem. Pág. 59.

16 GOULD, Jeffrey y LAURIA, Aldo. 1932 Rebelión en la oscuridad. Ed. Museo de la Palabra y la Imagen, El Salvador, 2008.

17 Ídem. Pág. 58.

18 MONTES, Segundo. El Compadrazgo, una estructura de poder en El Salvador. Ed. UCA Editores, El Salvador, 1979.

19 Montes, Segundo. "Levantamientos Campesinos en El Salvador". Realidad, revista de ciencias sociales y bumanidades. Núm. 1. Ene-feb 1988. Pág. 81. Ed. UCA, El Salvador, 1988.

20 LEIVA, Julio. Los Izalcos, testimonio de un indígena. Colección Bicentenario. Ed. Secretaría de Cultura de la Presidencia y Universidad de El Salvador, El Salvador, 2011.

21 Ídem. Pág. 17.

22 GOULD, Jeffrey y LAURIA, Aldo. 1932 Rebelión en la oscuridad. Pág. 175. Ed. Museo de la Palabra y la Imagen, El Salvador, 2008.

23 ANDERSON, Thomas. El Salvador 1932. Los sucesos políticos de 1932. Pág. 31. Ed. EDUCA, Costa Rica, 1979.

24 BENÍTEZ, Pablo. "El Salvador, 1932: Los Cofrades Insurrectos.” Revista Cultura, Núm. 105 enero/ marzo 2011. Pág. 100-120. Ed. Secretaría de Cultura de la Presidencia, El Salvador, 2011. 


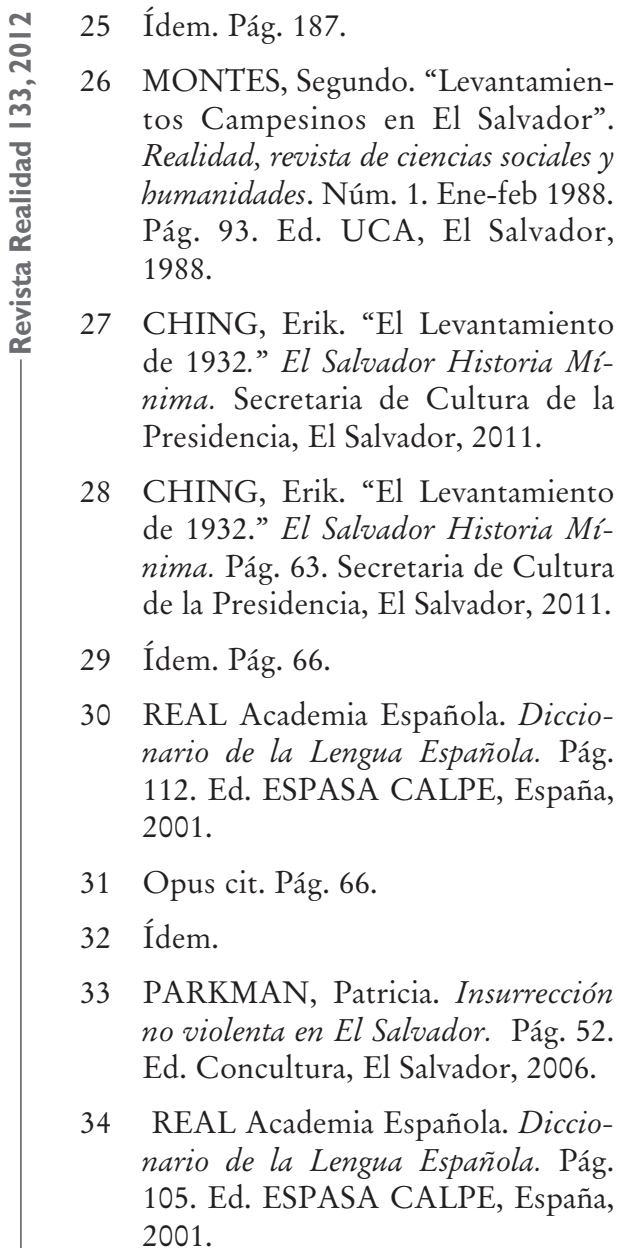

35 VALDÉS, Joaquín. "Declaración oficial del Ministro de los Ramos Guerra, Marina y Aviación.” Diario Oficial, 20 de febrero de 1932. Pág. 302. San Salvador, 1932.

36 ANDERSON, Thomas. El Salvador 1932. Los sucesos politicos de 1932. Pág. 133. Ed. EDUCA, Costa Rica, 1979.

37 PARKMAN, Patricia. Insurrección no violenta en El Salvador. Pág. 52. Concultura, El Salvador, 2006.
38 FUENTE, Héctor y otros. Recordando 1932: La Matanza, Roque Dalton y la Politica de la Memoria Histórica. Pág. 39. FLACSO, El Salvador, 2010.

39 Ídem. Pág. 54.

40 Ídem. Pág. 56.

41 ANDERSON, Thomas. El Salvador 1932. Los sucesos políticos de 1932. Pág. 196. Ed. EDUCA, Costa Rica, 1979.

42 GOULD, Jeffrey y LAURIA, Aldo. 1932, Rebelión en la oscuridad. Pág. 275. Ed. Museo de la Palabra y la Imagen, El Salvador, 2008.

43 WEITZ, Eric. Un siglo de genocidio: utopias de raza y nación. Ed. University Press. London, 2003.

44 Opus cit. Pág. 282.

45 Opus cit. Pág. 284.

46 Ídem.

47 LARA, Rafael. Política de la Cultura del Martinato. Ed. Universidad Don Bosco, El Salvador, 2011.

48 GOULD, Jeffrey y LAURIA, Aldo. 1932 Rebelión en la oscuridad. Ed. Museo de la Palabra y la Imagen, El Salvador, 2008.

49 FUENTES, Lindo y otros. Recordando 1932: La Matanza, Roque Dalton y la Política de la Memoria Histórica. Pág. 20. FLACSO, El Salvador, 2010.

50 LARA, Rafael. Política de la Cultura del Martinato. Pág. 28. Ed. Universidad Don Bosco, El Salvador, 2011.

51 Ídem. Pág. 70.

52 Ídem. Pág. 130. 
53 LARA, Rafael. Balsamera bajo la guerra fría, El Salvador 1932, bistoria intelectual de un etnocidio. Ed. Universidad Don Bosco, 2009, San Salvador.

54 Ídem, pág. 141.

55 CHING, Erik y otros. Las masas, la matanza y el martinato en El Salvador. Ensayos sobre el 32. Ed. UCA Editores, El Salvador, 2007

56 Ídem. Pág. 100.

57 Ídem. Pág. 102.

58 Ídem. Pág. 106 y 107.

59 Ídem. Pág. 110.

60 MEjÍA, José. “Censo Nacional. Población de la República Clasificada por Sexo, Nacionalidad, Domicilio, Raza, Instrucción, Propietarios y No Propietarios." Censo de Población de El Salvador 1930. Folio 2158. Pág. 7. En Biblioteca Virtual en Población Centro Centroamericano de Población. http://ccp.ucr. ac.cr/bvp/censos/El_Salvador/1930/ index.htm

61 ONU. Convención para la Prevención y la Sanción del Delito de Genocidio. "Artículo II de Las Partes Contratantes.” 12 de enero de 1951. Pág. 84. En http://www.un.org/ es/comun/docs/?symbol=A/ RES/260III

62 Ídem.

63 CONVENCIÓN sobre la Imprescriptibilidad de los crímenes de guerra y de los crímenes de lesa humanidad. 26 de noviembre de 1968. Artículo 1. Pág. 51. En http://www.un.org/es/comun/ docs/? symbol=A/RES/2391XXIII

64 CORPORACIÓN DE PROMOCIÓN Y DEFENSA DE LOS DE-
RECHOS DEL PUEBLO. "Sobre la Comisión Internacional de los Derechos Humanos de la ONU." Crímenes que sancionará la Corte Penal Internacional (CPI). Pág. 3. 09 de abril 2002. En http://www. codepu.cl/

65 ASAMBLEA NACIONAL. Suplemento del Registro Oficial No 578 Año III. Quito, Lunes 27 de Abril del 2009. Oficio No. SCLF-2009. Pág. 171. En www.estade.org/leyes

66 WHITAKER, Benjamín. Subcomisión de Prevención de Discriminaciones y Protección a las Minorias de la ONU. 1985. Pág. 2. En http://www. un.org/es/rights/

67 DÁVALOS, Pablo. "Ecuador: ley de etnocidio y genocidio: cuna batalla perdida?". ALAI, América Latina en Movimiento. 16 de abril de 2009, Bolivia, 2009. En http://alainet.org/

68 ASAMBLEA General de la ONU. Principios de cooperación internacional en la identificación, detención, extradición y castigo de los culpables de crimenes de guerra o crimenes de lesa humanidad. Diciembre de 1973. En www.oas.org

69 ASAMBLEA General de la ONU. Principios de cooperación internacional en la identificación, detención, extradición y castigo de los culpables de los crimenes de guerra o crimenes de lesa humanidad. Resolución 3074 (XXVIII). Pág. 2. 3 de diciembre de 1973. En www.oas.org

70 ORGANIZACIÓN de las Naciones Unidas. Estatuto de Roma de la Corte Penal Internacional. Distr. General A/CONF.183/9. 17 de julio de 1998. En www.derechos.net/doc/ tpi.html 
71 MARALINO, Ezequiel. Implementación y Dificultades de Implementación del Estatuto de Roma a la luz de la experiencia latinoamericana. Pág. 491 y 492. Jan Editores. Chile, 2006.

72 ORGANIZACIÓN de las Naciones Unidas. Estatuto de Roma de la Corte Penal Internacional. Distr. General A/CONF.183/9. 17. Art. 7 Núm. 2 Inc. H. Julio de 1998. En www.derechos.net/doc/tpi.html

73 CONSEJO de Seguridad de la ONU. Estatuto del Tribunal Internacional para la Ex-Yugoslavia. Mayo de 1993. En http://www.espaciosjuridicos.com.ar/datos/OTROS TRATADOS/

74 Ídem, Pág. 1.

75 REVUELTAS, Andrea. Modernidad y Mundialidad. Pág. 4. Ed. ITAM, México, 1990.

76 HINKELAMMERT, Franz. Hacia un crítica de la razón mítica, el laberinto de la modernidad. Ed. Dríada, México, 2008.

77 Ídem. Pág. 57-58.

78 VILLENA, Sergio. "Walter Bejamin o la historia a contrapelo." Revista de Ciencias Sociales, Universidad de Costa Rica 203, vol. II, núm. 100. Pág. 98. Ed. ALyC UCR, Costa Rica, 2003.

79 Ídem. Pág. 99.

80 HINKELAMMERT, Franz. Hacia un crítica de la razón mítica, el laberinto de la modernidad. Pág. 62. Ed. Dríada, México, 2008.

81 Ídem. Pág. 63.

82 AZIZ, Philippe. Los Criminales de Guerra. Pág. 67. Ed. DOPESA, España, 1974.
83 Ídem. Pág. 70.

84 ONU. Convención para la Prevención y la Sanción del Delito de Genocidio. "Artículo II de Las Partes Contratantes.” 12 de enero de 1951. Pág. 84. En http://www.un.org/ es/comun/docs/?symbol=A/ RES/260III

85 HINKELAMMERT, Franz. Hacia un crítica de la razón mítica, el laberinto de la modernidad. Pág.65. Ed. Dríada, México, 2008.

86 MATAMOROS, Fernando. Memoria y Utopia en México. Pág. 51. Ed. Herramienta Ediciones, México, 2009.

87 LE GOFF, Jaques. Historia y Memoria. Pág. 33. Ed. Foliohistorie, Paris, 1988.

88 ESPARZA, José Javier. "El etnocidio contra los pueblos: mecánica y consecuencias del neocolonialismo cultural." www.paginadigital.com. ar/articulos/2004/2004terc/educacion1/e106068-4pl.asp

89 SUMMER, William. Caminos de Folkways. Pág. 7. Ed. Nuevo Mundo, 1906.

90 MATAMOROS, Fernando. Memoria y Utopía en México. Pág. 63. Ed. Herramienta Ediciones, México, 2009.

91 LEVINAS, Emmanuel. ¿Es fundamental la ontología? Revue de métaphisique et de morale, número 1 , enero-marzo de 1951. Traducción de José Luis Pardo en Entre Nosotros. Ensayos para pensar en otro, PreTextos, Valencia, febrero de 2001, p. 13. España, 2001.

92 ZIZEK, Slavoj. "Resurrecting the left (resucitar a la izquierda).” 30 de Noviembre de 2009. Reuters. Pág. 1. 
93 DUSSEL, Enrique. Ética de la Liberación en la Edad de la Globalización y la Exclusión. Pág. 417. Editorial Trotta, Argentina, 1998.

94 ESPARZA, José Javier. "El etnocidio contra los pueblos: mecánica y consecuencias del neocolonialismo cultural." En www.paginadigital. com.ar/articulos/2004/2004terc/ educacion1/e106068-4pl.asp

95 Ídem.

96 Ídem.

97 POIRIER, L. Entidades Colectivas y Relaciones Interculturales. Pág. 38. Editorial Complexe Bruselas, Bélgica, 1978.

98 Opus cit.

99 Hinkelammert, Franz. El Apocalipsis como visión de la historia occidental. www.pensamientocritico.info Pág. 1, febrero de 2004.

100 Ídem.

101 Filósofo de origen español. Su obra se centra en el concepto de realidad y sensibilidad sentiente. Plantea que el sujeto se encuentra situado en la historia como realidad de suyo. En Inteligencia sentiente: inteligencia $y$ logos. Ed. Alianza, España, 1982.

102 Opus cit.

103 BENJAMIN, Walter. Tesis de Filosofía de la Historia. Ed. Taurus Madrid, España, 1973.

104 Ídem. Pág. 6.

105 BLOCH, Ernest. El Principio Esperanza. Ed. Trotta, Argentina, 2007.

106 HINKELAMMERT, Franz. El Apocalipsis como visión de la bistoria occidental. Pág.8. www.pensamientocritico.info, 2004.

107 CCRI-EZLN. "Manifiesto zapatista en náhuatl. En Cuarta declaración de la Selva Lacandona, enero 1996.” http://enlacezapatista.ezln.org.mx/

108 ADORNO, Theodor. Crítica, cultura y sociedad. Pág. 106. Ed. Siglo XX, México, 1989. 